\title{
Rethinking the Risk Management Process for Genetically Engineered Crop Varieties in Small-scale, Traditionally Based Agriculture
}

\author{
$\underline{\text { David A. Cleveland }}^{1}$ and Daniela Soleri ${ }^{1}$
}

\begin{abstract}
Proponents of genetically engineered (GE) crops often assume that the risk management used in the industrial world is appropriate for small-scale, traditionally based agriculture in the Third World. Opponents of GE crops often assume that risk management is inappropriate for the Third World, because it is inherently biased in favor of the industrial world. We examine both of these assumptions, by rethinking risk management for GE crops and transgenes, using the example of maize transgene flow from the U.S. to Mexico. Risk management for the Third World is a necessary first step of a broader benefit-cost analysis of GE crops, which would include comparisons with existing varieties and with alternative varieties such as transgenic farmer varieties and organic varieties. Our goal is to use existing information on GE crops and on the social and biological characteristics of Third World agriculture to identify key processes that need to be considered in risk management, and the additional research required to adequately understand them. The four main steps in risk management are hazard identification, risk analysis (exposure $\mathrm{x} \mathrm{harm),}$ risk evaluation, and risk treatment. We use informal event trees to identify possible exposure to GE crops and transgenes, and resulting biological and social harm; give examples of farmers' ability to evaluate social harm; and discuss the possibilities for risk treatment. We conclude that risk management is relevant for Third World agriculture, but needs to be based on the unique biological and social characteristics of small-scale, traditionally based agriculture, including the knowledge and values of Third World farmers and consumers.
\end{abstract}

Key Words: agricultural biotechnology; biological diversity; biological invasion; crop genetic resources; farmer participation in risk evaluation; gene flow; genetic engineering; risk analysis; risk management process; traditionally based agricultural systems compared with industrial agriculture systems; transgenes; transgenic crop varieties

\section{INTRODUCTION}

There is heated global debate over whether genetically engineered (GE) crop varieties (also known as "genetically modified" crops) will be good or bad for the environment and society. Reports of the presence of transgenes from GE maize in farmers' traditional crop varieties (FVs, also referred to as "landraces") in Oaxaca, Mexico in the fall of 2001 (Dalton 2001, Quist and Chapela 2001) resulted in a "maize scandal" (Mann 2002a) that further intensified and polarized the debate over GE crops, and focused world attention on the effects of GE crops and transgene flow on small-scale, traditionally based farmers in the Third World (hereafter "farmers" or "Third World farmers"), especially in areas of crop origins and diversity like Oaxaca. Dramatically contradictory statements about these effects raise questions about the roles of science and values in the risk management process (hereafter "risk management") for GE crops. Positions on both sides of the debate conflate statements about the way things are, based on objective scientific observation and measurement, with statements about the way things ought to be, based on subjective values (Levidow 2003), a 
common problem in science (Costanza 2001). A key assumption of GE crop proponents is that potential risks of GE crops for Third World agriculture are not significantly different from those in industrial countries, or that differences in traditional systems require change and, therefore, risk management carried out in the industrial world is seen as applicable to the Third World. In contrast, opponents see Third World agriculture and farmers as fundamentally different than those in the industrial world, and risk management as inappropriate and inherently biased in favor of GE crops.

Proponents of GE crops vigorously promote them as a key component in meeting the demand for increasing food production sustainably in the Third World (DeVries and Toenniessen 2001, James 2003, Qaim and Zilberman 2003, Food and Agriculture Organisation (FAO) 2004a). Many see this as entirely compatible with, indeed as dependent on, ensuring profit for private agricultural biotechnology companies (National Research Council of the National Academies (NRC) 1990, Victor and Runge 2002) whose GE crop varieties account for almost all GE crops grown globally. These companies promote the environmental, economic, and nutritional benefits of GE crops for subsistence farmers in developing countries (Monsanto Company 2004, Syngenta 2004). However, many international agencies supporting the development of GE crops for the Third World see public involvement in GE crop development as essential, because private companies are unlikely to invest in varieties for poor Third World farmers (e. g., FAO 2004a). The Rockefeller Foundation, one of the main sponsors of the Green Revolution, supported establishment in 2003 of the African Agricultural Technology Foundation to facilitate public-private partnerships to bring GE crops and other agricultural technologies to farmers (Conway 2003). A collaboration to develop GE maize varieties among the CGIAR, the government of Kenya, and Syngenta assumes that it will provide a net benefit to farmers, and the publicity does not mention the need for risk management to assess potential harm, but rather emphasizes research on benefits: "conducting studies on practices [that] enable farmers to use $B t$ maize productively and on how the varieties will fit into the environment" (CGIAR 2004). The assumption, often implicit, is that risk management in the industrial world, which has led to the commercialization and widespread planting of GE crops, is adequate for the Third
World (König 2003, Vasil 2003:850, 851). Sometimes it is explicit (USDA GIPSA 2002). Although improving the biosafety capability of Third World countries to carry out risk management for GE crops is often emphasized, the implicit a priori assumption is that GE crops have net benefits and should be promoted (e.g., FAO 2004a). Proponents often see U.S. risk management for GE crops as sound science and characterize opponents as being ignorant and antiscientific, routinely dismissing skepticism or opposition as due to ignorance or manipulation by self-serving environmental groups (Borlaug 2000, Chrispeels 2000, Giddings 2002, Miller 2003).

Opponents of GE crops vigorously attack them as inappropriate for the Third World. They see the profit motivation of private corporations as incompatible with the goal of alleviating hunger and helping farmers, and GE crops as making problems in the Third World worse (ETC Group 2003, Hickey and Mittal 2003, McAfee 2003). They point out that Third World farmers are unlikely to benefit even from GE crops developed specifically for them, as with the GE potato in Mexico (Massieu et al. 2000), or the well-known virus-resistant GE papaya (GRAIN 2004a), originally developed in the public sector for Hawaii (Gonsalves 1998), with other varieties being developed for the Third World (Bau et al. 2003, Fermin et al. 2004). Opponents suggest that risk management is unscientific because it is strongly influenced by the self interest of corporations and the governments that support them, for example that corporations use trade agreements to "force poorer countries to accept exports of genetically modified seeds and products" (DeSantis 2003:5, Ribeiro 2004). The risk management process that has resulted in the widespread commercialization and planting of GE crops in the US and other countries is seen as being fundamentally inappropriate for the Third World (Greenpeace 2003). They see the Third World as unique, e.g., because it is home to most of the world's crop genetic diversity in the form of traditional crop varieties and crop wild relatives. They claim the rubric "sound science" is used by proponents of GE crops as an ideological weapon (Leiss 2001), but many of their arguments are unscientific because they have a vested financial or career interest in the acceptance and spread of GE crops. A supporter of GE crop technology, and a key scientific participant in the creation of the FlavrSavr ${ }^{\mathrm{TM}}$ tomato, describes this among the Calgene scientists she worked with as "an inability 
on the part of at least some members of the probiotech scientific community to face and deal with the facts on the subject" (Martineau 2001:231).

This controversy suggests that the process of risk management, which is meant to promote decisions in the broad social interest (NRC 1996), appears to be failing. Instead there is a polarized debate jeopardizing the development of risk management based on fact and values, thus reducing both the possibility that GE crops could benefit Third World farmers (Conway 2003), and the possibility of protecting these farmers from any potential costs (NRC 2002, ETC Group 2003, Hickey and Mittal 2003). It also obscures comparisons with alternatives to GE crops, e.g., organic varieties (Jordan 2002) or conventional modern varieties (MVs) (NRC 2002). Often missing in the debate about risk management are: a) a middle ground, relatively free of ideological assumptions, to more objectively evaluate both empirical data and subjective values; b) adequate information on the biophysical and social characteristics of Third World agriculture; and c) direct involvement of farmers themselves, including their knowledge and, especially in the evaluation stage, their values.

Despite the disagreements about GE crops and appropriate risk management for them, especially in the Third World, both proponents and opponents generally agree that there is: a) dramatic spread of GE crops globally, from 1.7 to 67.7 million hectares between 1996 and 2003, being $25 \%$ of the total area sown to the four major transgene crop species (James 2004), including in the Third World, where over 20 million hectares were sown to GE crops in 2003, 30\% of the global area; b) increased probability of transgene flow, including into centers of diversity, e.g., maize transgenes documented in Mexican farmers' varieties (FVs) (Alvarez-Morales 2002, Alvarez-Buylla 2003); c) rapid development of third-generation GE crops, including maize, that produce pharmaceuticals and industrial chemicals (Ellstrand 2003c, Union of Concerned Scientists (UCS) 2003); and d) transgene flow, the effects of which may often be irreversible (Ellstrand 2003a).

Therefore, our emphasis is on analysis of the potential for negative effects of GE crops in the Third World using the risk management framework. This step is necessary to provide estimates of costs of GE crops for a broader analysis, which includes potential benefits of GE crops, as well as benefits and costs of alternatives to GE crops. In this paper, we outline our rethinking of risk management for traditionally based agriculture in the Third World, which questions the assumptions of both GE crop proponents and opponents, and is based on current knowledge of GE crops and traditionally based agriculture, focusing on $B t$ maize in Mexico.

\section{A SOCIAL AND BIOLOGICAL PERSPECTIVE ON GE CROP VARIETIES IN THE THIRD WORLD}

A key ecological concept widely accepted by scientists who study biological invasions is that the effect of a novel organism is context specific (Levine et al. 2003, Simberloff 2004). Many scientists stress that GE crops and transgenes are biological novelties, and that the consequences of introducing them into an agricultural system will depend on the specific contexts (Gepts 2002, NRC 2002:4 and 28-36, Ellstrand 2003b; see also NRC 2004a, Ribeiro 2004), including "genomic, physical and biological environments [and]...societal values" (NRC 2002:4, 28-36), and including relevant spatiotemporal scales (NRC 2002:195, Snow et al. 2004).

On the global scale, the extrapolation of conclusions from risk management in the industrial world to the Third World is an important instance of failing to take into account the specific characteristics of the site into which novel organisms are being introduced-available data discussed below demonstrate that Third World agriculture is very different from that of the industrial world. Important components of this difference are the knowledge and values of Third World farmers, who have very limited access to information about GE crops and to participation in risk management. Therefore, extrapolation of U.S. findings to Third World agriculture is considered by some to be scientifically invalid (NRC 2002:176).

In this section, we briefly review the Mexican maize scandal that intensified discussion of the potential impact of GE crops in the Third World. We then discuss some of the important ecological, biological, and social characteristics of traditionally based, small-scale agriculture in the Third World. 


\section{The Mexican GE Maize Scandal}

A major event in the story of GE crops in the Third World has been the "maize scandal" in Mexico (Mann 2002a) - it further intensified and polarized the debate over GE crops, and focused attention on the Third World. Debate about this case in the public and scientific media illustrates the contradictory assumptions of GE crop proponents and opponents, and the lack of specific data on Third World agriculture.

International reports of maize transgenes in FVs in Mexico first appeared in fall 2001 in the journal Nature. In September, a news article reported the partial results of a Mexican environment ministry study, showing transgenes in local FVs of maize in 15 of 22 areas in the southern states of Oaxaca and Puebla (Dalton 2001), and in November, a research article by Quist and Chapela of the University of California at Berkeley (UC Berkeley) reported the presence of transgenic constructs in maize FVs from remote areas of Oaxaca (Quist and Chapela 2001). Quist and Chapela's article was a lightening rod for the scientific and public debate, and was interpreted in terms of preexisting positions of proponents and opponents. Nature subsequently published two letters criticizing Quist and Chapela's methods and interpretations (Kaplinsky et al. 2002, Metz and Fütterer 2002), and a response providing new data (Quist and Chapela 2002), along with an unprecedented editorial statement that data in the original paper did not justify publication (Nature 2002). Following this, Nature published two letters critiquing the critiques and Nature's editorial stance (Suarez 2002, Worthy et al. 2002), claiming criticism of Quist and Chapela was related to a $\$ 25$ 000000 grant to UC Berkeley from the agricultural biotechnology company Syngenta that Chapela had opposed.

Opponents and proponents of GE crops in the Third World have interpreted the reported unintentional flow of transgenes into FVs in polarized ways. It has been stated that it constitutes a "crime against all the indigenous peoples and farmers who have for millennia protected [maize], for humanity to be able to enjoy" (Melina Hernández Sosa, of UNOSJO, a Oaxacan non-governmental organization (NGO), cited in Vélez Ascencio 2003). On the other hand, proponents of GE crops have stated that the transgenes are a welcome addition, which augments Mexican farmers' traditional crop varieties and agriculture, and which they get for free (AgBio
View 2002). Such widely held contradictory viewpoints make it extremely difficult for society to agree on how to maximize potential benefits and minimize potential risks of GE crops in the Third World.

A major institutional response to the maize scandal was a task force, "Maize and biodiversity: the effects of transgenic maize in Mexico," appointed by the Commission for Environmental Cooperation of North America (CEC). The CEC was established by Canada, Mexico, and the United States to support cooperation in implementing the North American Agreement on Environmental Cooperation (NAAEC), the environmental side-accord to the Norht American Free Trade Agreement (NAFTA). Public commentary during a presentation of the draft report was strident, and focused on farmers' rights in their maize FVs (Nadal and Wise 2004:20), reflecting mistrust caused by previous experiences and lack of participation, especially among low-resource, rural, and indigenous populations, as observed by one of us (DS). The U.S. government appears to object to the overall approach of the report (CEC 2004), which emphasizes the uniqueness of the situation in Mexico, as illustrated in a public letter by the chair of CEC's Joint Public Advisory Committee:

What we learned from our participation is that the conservation of biodiversity cannot be separated from the protection of cultural diversity. A better understanding and respect for the human and social context is called for in this debate. Indeed all analyses should be based on a broad understanding of sustainable development and the interplay of environmental, economic, social and cultural impacts. - Tingley (2004)

Understanding the potential risks posed by maize transgene flow into FVs in Mexico is a critical case study for understanding the issue of GE crops in the Third World because:

1. Maize is an important world crop (third in production after rice and wheat) (FAO 2004b), and the main species of choice for third-generation GE crops producing industrial chemicals and pharmaceuticals (UCS 2003).

2. Mexico is a center of biological diversity for 
many crops, and Oaxaca is within the region where maize was domesticated (Matsuoka et al.2002) and is a center of biological diversity for maize (Aragón Cuevas 1989).

3. Mexico is rich in cultural diversity, with a large proportion of its population dependent on maize production, using FVs (Aragón Cuevas 1995, Aquino et al. 2001).

4. The U.S. is the world leader in developing, promoting, producing, and regulating GE crops, with 42.8 million ha planted in GE crops in 2003 (63\% of the global area planted to GE crops) (James 2004).

5. Mexico and the U.S. share a long common border, and since implementation of NAFTA in 1994, Mexico annually imports up to $25 \%$ of maize consumed from the U.S.; Mexico is the second-largest recipient of U.S. maize exports (about $11 \%$ of total maize exports) (Zahniser and Coyle 2004:4); and many Mexican farmers migrate to the U.S. for work, often returning later to Mexico (Cohen 2001).

6. Reports of transgenes in Oaxacan FVs have been a central factor in policy decisions affecting GE crops, including the European Union's decision in May 2004 to require labeling of all GE food and feed (European Economic and Social Committee (EESC) 2002), and the Mexican government's proposal in 2002 to ban movement and release of all GE organisms including those used in research (Mann 2002b).

The next two sections outline some of the important ecological, biological, and social characteristics of traditionally based, small-scale agriculture in the Third World, specifically describing their growing environments and genotypes, and the structure of their seed and food systems in contrast to those of industrial agriculture.

\section{Growing Environments and Genotypes}

Growing environments and genotypes of Third World farmers differ in important ways from those most plant breeders and agronomists in industrial countries are familiar with. Farms often consist of a number of small, scattered fields, with marginal growing environments-relatively high levels of stress, and of temporal and spatial variability. For example, although the average size of maize grain farms in the U.S. in 2003 was 79.2 ha (USDA National Agricultural Statistics Service (USDA NASS) 2004), in Oaxaca over 76\% of maize farms are smaller than 5 ha (Instituto Nacional de Estadística Geografía e Informática (INEGI) 2001). In one of the Oaxacan communities where we are working, the average farm size is 3.7 ha, and the average maize field size is 0.8 ha (Soleri et al. 2003). Farmers use low levels of external inputs, have limited access to government programs and markets, and have limited influence on policies affecting them, resulting in high production risks (Ellis 1993, Hardaker et al. 1997).

Farmers often continue to use FVs, even when MVs are available, because they may be better adapted to marginal growing environments, and because MVs may be agronomically, culinarily, and economically inappropriate (Evans 1993, Ceccarelli et al. 1994, Heisey and Edmeades 1999). Farmers value FVs for agronomic traits, such as drought resistance, pest resistance, and photoperiod sensitivity, as well as for traits contributing to storage, food preparation, taste, market value, and appearance (Smale 2002). Farmers' varieties include landraces, traditional varieties selected by farmers, MVs adapted to farmers' environments by farmer and natural selection, and progeny from crosses between landraces and MVs (sometimes referred to as "creolized" or "degenerated" MVs). The genetic diversity of farmer-managed FVs is presumed to support broad resistance to multiple biotic and abiotic stresses, making them valuable not only for farmers, because they decrease the production risks in marginal environments, but also for plant breeders and conservationists, as the basis for future production in industrial agriculture (Brown 1999). Many centers of origin and diversity for crop species are also dominated by Third World farmers, making them critical for the in situ conservation of crop genetic diversity (Harlan 1992). 


\section{Seed and Food Systems}

In industrial agriculture, food production, food consumption, crop improvement through selection (plant breeding), seed multiplication, and crop genetic resources conservation are specialized and physically and structurally separated, and farming is often considered to be primarily a business (Todaro 1994). In Third World agriculture, these functions are combined together and centered within the farm household and community (Soleri and Cleveland 2004), as described below.

\section{Production}

Food production relies on household labor (Ellis 1993), is currently essential for feeding the world population, and will likely be necessary to feed the future population even with production increases in large-scale, industrial agriculture (Heisey and Edmeades 1999). It has been estimated that by 2025 , three billion people will depend on agricultural production in small-scale Third World systems (Falkenmark 1994, cited in Evans 1998, Goklany 2002). Most households sell some portion of their production in the market, but they are incompletely integrated into these markets (Smale 2002). Farmers' production knowledge combines understanding based on theory and empirical observation with values about the social and religious significance of farming, often specifically focused on FVs (Soleri et al. 2002).

\section{Consumption}

Farm families rely on their own food production for a significant proportion of their food, and FVs are valued for traits that contribute to storage, food preparation, taste, color, texture, and specific uses (e.g., maize varieties grown for husks used in tamale production) (Soleri and Cleveland 2001). These specialized uses mean some FVs have high market values (Smale 2002).

\section{Improvement and seed multiplication}

Farmer selection of new varieties in relatively isolated environments was responsible for the tremendous increase in intraspecific crop diversity following domestication (Harlan 1992, Matsuoka et al. 2002), and continues today. It has been best documented at a local level in vegetatively propagated crops (Elias et al. 2001). For allogamous crops such as maize, many farmers may generally not be interested in changing their varieties through selection, but rather in maintaining in them qualitative phenotypic traits of interest (Pressoir and Berthaud 2004b), and can be successful even in the presence of high rates of gene flow at other loci (Louette et al. 1997, Pressoir and Berthaud 2004a). Seed multiplication is usually not distinguished from food production, and farmers produce a high proportion of their seed (Louette et al. 1997, Soleri et al. 2000).

\section{Conservation}

Farmers conserve crop genetic diversity of FVs in situ in their fields and storage containers (Qualset et al. 1997). Most in situ conservation is done indirectly-perhaps often unintentionally-as a result of using or selecting and saving FV seeds each year for planting (Louette and Smale 2000, Soleri et al. 2000).

\section{ANALYTICAL TOOLS}

Described here are the two analytical tools we used in our rethinking of the risk management process for GE crops and transgenes in Third World agriculture: the established steps in risk management, and event trees.

\section{Risk Management Process}

The risk management process is the standard institutional approach to risk in the industrial world, not only for GE crops, but for new technologies generally and for novel biological entities, such as invasive species (NRC 1996, 2002). There are four key steps in this process, although they may be organized and labeled in different ways: 1) identification of a hazard (or potential risk); 2) analysis of the probability of a) exposure to hazard and b) harm resulting from exposure (Risk $=\mathrm{P}(\mathrm{E})$ $\mathrm{x} \mathrm{P}(\mathrm{H})$ ); 3) evaluation (or perception, assessment) of harm; and 4) treatment (or management, regulation) of risk by reducing exposure and harm (e.g., Hardaker et al. 1997, Conference of the Parties to the Convention on Biological Diversity (COP CBD) 2000, Dietz et al. 2002, NRC 2002:54-55).

However, there is much controversy about the way in which these steps are carried out, and about the broader context within which risk management 
functions (for an example with $B t$ maize in the European Union (EU) see Levidow 2003). We outline four critical issues contributing to the controversy in risk management for GE crops, and how we apply them to rethinking this process for GE crops in the Third World.

\section{Numerical probabilities or delineation of broad issues}

Standard approaches in risk analysis focus on a narrow range of effects, and assume that valid and generalizable numerical probabilities can be calculated from these (NRC 1996:157, 113-114, Ravetz 2003). We believe that, in the case of GE crops for the Third World, this approach is especially inappropriate at this time, because the issues are unclear, and expert knowledge limited. In addition, we agree with the argument that valid risk management needs to address broad social, environmental, economic, and ethical issues for specific populations, and incorporate a range of individual perspectives (NRC 1996:156-158), and that the "international obligations of government must be linked to a case-by-case analysis" of the GE organism involved (NRC 2004a:194). This is especially true in the case of GE crops for the Third World because it is probable that decision makers (viz. in the industrial world) will expose others (viz. Third World farmers and consumers) to risks that decision makers themselves will not directly bear (Freudenberg 1988, CEC 2004). Therefore, as most appropriate at this stage in our understanding (Economic and Social Research Council (ESRC) 1999, Ravetz 2003), we take a more open, qualitative approach that directly acknowledges this complexity; we identify potential for exposure and harm, and do not attempt numerical probabilities.

\section{Combining risk management with benefit-cost analysis}

Risk management for industrial and natural hazards (Lewis 1990, NRC 1996) and agriculture (Hardaker et al. 1997), including GE crops (NRC 2002, 2004a), usually focuses on harm ("downside risk"). In the case of a new technology such as GE crops, it is desirable to consider good as well as harm (Goklany 2002), and to compare the net effect with that of conventional and alternative technologies (NRC 2002) using benefit-cost analysis, as outlined in Fig. 1.

Appropriate varieties for comparison to GE crops include existing, conventional, nontransgenic MVs and FVs, as well as alternatives to existing conventional MVs and FVs for achieving more sustainable agriculture, which could include varieties for organic agriculture (Jordan 2002) and transgenic FVs. It is important to compare GE crops with conventional MVs and FVs because MVs have caused much harm as well as good in the Third World (NRC 2002), and FVs have unique benefits for farmers, including adaptation to local growing environments and desired taste, but are often deficient in traits desired by farmers, such as yield and disease resistance (Brown 1999). Alternatives to existing, as well as new, GE varieties also need to be considered. Some plant breeders have noted that past technological advances in plant breeding, e.g., hybrid maize and highly responsive green revolution varieties, were accepted without serious scientific scrutiny of alternatives that might have generated less social and environmental harm and produced more benefits (Simmonds and Smartt 1999).

However, risk management and benefit-cost analysis are only beginning to be combined in a rigorous way (Wong et al. 2003), including to GE crops (Farrow 2004), and although comparison to alternatives is frequently done in an informal way by both proponents and opponents of GE crops, an adequate analysis will require much additional research. One trial run of comparative benefit-cost for $B t$ maize has been made in Kenya on a very limited, exploratory scale, and has identified the need for much more data (Nelson et al. 2004). In this paper, therefore, we focus on risk management as the logical first step in an overall assessment of GE crops through comparative benefit-cost analysis.

\section{Facts and values}

Standard approaches tend to assume that scientists or professional managers are in charge of risk management, and that the most important part is risk analysis, based on objective, scientific criteria (NRC 1996). However, an increasingly prominent view of science is that it is inevitably influenced by value-based assumptions or "preanalytic visions" (Cleveland 2001, Costanza 2001), and therefore, so is science-based risk analysis (ESRC 1999, Levidow 2003, Ravetz 2003). Positions on both sides of the GE crops debate conflate statements about the way things are, based on objective scientific observation and measurement, with statements about the way things ought to be, based 
Fig. 1. Flow diagram illustrating the combination of risk management for GE crops in the Third World (green) with cost-benefit analysis comparing GE with other types of crop varieties (blue), including integration of new data available through post-commercialization monitoring. GEV = GE crop variety; FV = farmer variety; $\mathrm{MV}=$ modern variety, $\mathrm{AV}=$ alternative variety, $\mathrm{P}=$ probability, $\mathrm{R}=$ risk.

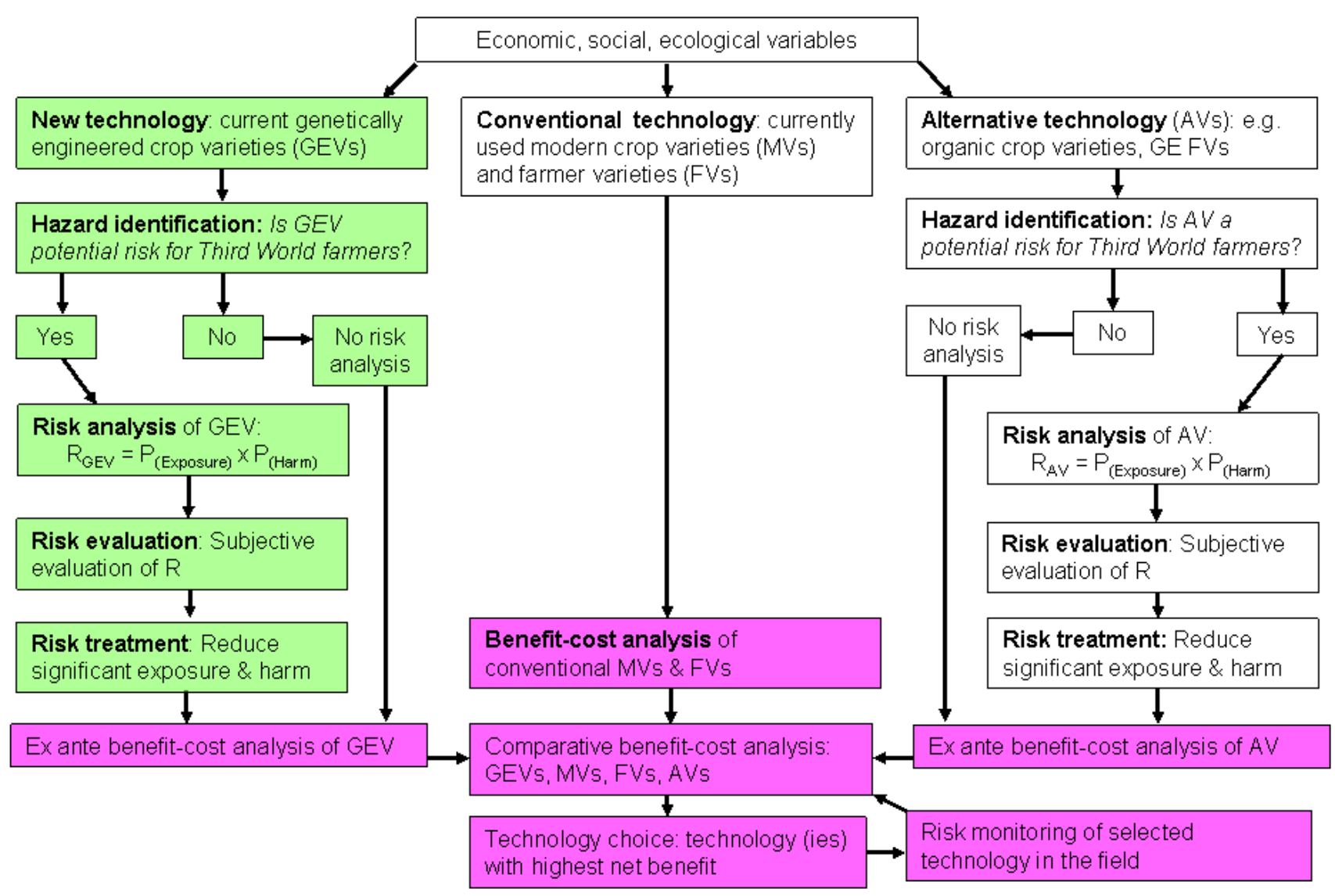

on subjective values-a common problem in scientific discourse (Costanza 2001). Even statistics are based on value assumptions, e.g., in determining the confidence intervals and degree of sensitivity (Andow 2003a, Ravetz 2004). Genetically engineered crops have been an exceptionally contentious technology, and risk management for them reflects the general situation just described. In this paper, we analyze assumptions made in the debate about GE crops, and try to be as transparent as possible about our own assumptions.

\section{Participation}

Although it has been argued that risk management serves two functions simultaneously, aiding decision making and gaining public trust, it can also be argued that these two functions are inseparable (NRC 2002). It is increasingly agreed that lack of public trust in GE crops is caused in part by a lack of participation in risk management, and this may be especially true from the perspective of the Third 
World (e.g., Taylor 2003). Results of some surveys suggest that the public view their participation in technology development and risk management positively, thus increasing pressure for public participation (Frewer 1999, Frewer et al. 2002). At least in Europe, there may be an institutional shift away from top-down risk management that privileges scientists' knowledge, to a more inclusive approach, providing greater public involvement and inclusion of ethical issues (Frewer 2003). Therefore, input from the public potentially affected by the new technology is essential, not only in evaluating risks, but in all four steps of the process (ESRC 1999, Martineau 2001, NRC 2002, Frewer 2003, Ravetz 2003), as well as in benefit-cost analysis (Nelson et al. 2004). Although results of many surveys and focus groups of consumers, and a few of farmers, are available for the industrial world, we know of no published surveys of Third World farmers. We assume that risk management, especially the risk evaluation component, of GE crops for the Third World, will have to include farmers themselves, and have provided suggestions and examples for how this could be done.

\section{Event Tree Analysis}

Based on the research literature on GE crops and Third World agriculture, and our own experience working with farmers and plant breeders in the Third World (Cleveland et al. 2000, Soleri et al. 2002), including our current project interviewing farmers in Mesoamerica about GE crops (Soleri et al. 2003, Cleveland et al. 2004), we constructed informal event trees to identify potential exposure and harm.

Event trees are a tool used in risk analysis to estimate the probability of risk of one or more hazards given an initial event, but they are not based on an assumption that a hazard exists (Haimes 1998). Event tree analysis has been used extensively for industrial technologies, but rarely in agriculture, although the NRC has recommended more research to evaluate the usefulness of event tree analysis for GE crops (NRC 2002:96-98). Event trees usually include numerical probabilities based on quantitative or qualitative estimates (Huang et al. 2001). However, because so little is known about the effects of GE crops and transgenes in traditional agriculture, and because traditional agriculture has high variability at small scales, we use "informal" event trees to qualitatively illustrate processes and potential risks, as a guide to research needed to provide the quantitative data necessary to estimate numerical probabilities. This approach is similar to the use of flowcharts to assess possible ecological hazards of GE organisms (Kapuscinski 2002), or in pathway analysis to identify potential exposure (Birch et al. 2004).

\section{GE CROPS AND TRANSGENES AS POTENTIAL HAZARDS}

"Hazard identification is one of the most subjective and potentially contentious elements of risk analysis" (NRC 2002). For example, although many view transgene pollen or seed flow itself as a potential hazard (Ellstrand 2003b), others do not, stating that transgene pollen flow from herbicideresistant GE crops, or even the subsequent emergence of herbicide-resistant strains of weeds, is not a hazard, and only the potential effects of resistant strains should be viewed as hazards (Nature Biotechnology 2002).

We review evidence that GE crops are a hazard in the Third World because: 1) assumptions that they are not a hazard there are based on inappropriate extension of risk management from the industrial world; 2) a key component of hazard identification is substantial equivalence, which is often flawed in application; and 3) GE crops and transgenes can be biologically invasive. Still, even if they are considered to be hazards, it is likely that, as more data become available, certain types of GE crops (e. g., autogamous crops with transgenes from within the same genus or species, and without antibiotic resistance marker genes) may be less hazardous and require less attention than other types (e.g., pharmaceutical maize).

\section{Extending Risk Management from Industrial to Traditionally Based Agriculture}

The extension of risk management from the industrial world to the Third World generally ignores the major differences in agriculture between them, as discussed above. It is commonly assumed that the regulatory system in industrialized countries where GE crops are being developed and promoted is adequate for Third World countries, and the U.S. promotes the shipment of GE seed and grain, including food aid, to the rest of the world as fully regulated. Although the U.S. government states that it supports research on potential risks "to 
biodiversity from bioengineered products in the specific environmental and agroecological environments of developing countries" (U.S. Agency for International Development (USAID) 2003), it also promotes GE crops as safe for the Third World (USAID 2002, USDS Bureau of Economic and Business Affairs (USDS BEBA) 2003), and supports international risk management that is "science-based and is aligned with U.S. safety standards" (USDA Animal and Plant Health Inspection Service Biotechnology Regulatory Services (USDA APHIS BRS) 2004). The USDA is not mandated to include consideration of risk for locations outside of the U.S. (NRC 2002:176), yet the information used by the USDA to accompany GE crop exports strongly implies that, because they have been approved in the U.S., they are without risk for the rest of the world. For example, USDA letterhead statements for international exports of transgenic maize state that it has "completed the necessary review under the U.S. regulatory process for determining the safety of new agricultural biotechnology products. This well coordinated regulatory process sets U.S. standards for human, animal, and plant health, and environmental safety. The transgenic corn used for domestic purposes is the same as corn used for export." (USDA GIPSA 2002). The official U.S. response to the CEC report discussed above (in The Mexican GE Maize Scandal) includes claims that U.S. risk management is the best in the world, and implies that concerns about the effect of GE maize in Mexico in the report were scientifically unfounded (CEC 2004:50). Indeed, a key argument for regulation by proponents of GE crops is to reassure the world, including the Third World, that GE crops are safe (NRC 2002), which many see as important in order to secure and increase the profits of private agricultural biotechnology corporations (e.g., Victor and Runge 2002). Therefore, claims that GE crops are not a hazard in the Third World, based on extension of $U$. S. risk management, appear unfounded.

\section{Substantial Equivalence}

A key component of hazard identification is the concept of substantial equivalence, which has been used informally since the beginning of GE crop regulation for assessing the hazard status of GE crops, and since 1992 (Organisation for Economic Co-operation and Development (OECD) 1992) has been a formal international principle (Kok and Kuiper 2003). "The concept of substantial equivalence embodies the idea that existing organisms used as food, or as a source of food, can be used as the basis for comparison when assessing the safety of human consumption of a food or food component that has been modified or is new....If the new or modified food or food component is determined to be substantially equivalent to an existing food, then further safety or nutritional concerns are expected to be insignificant" and "Such foods, once substantial equivalence has been established, are treated in the same manner as their analogous conventional counterparts" (OECD 1992:11, 12). The concept of substantial equivalence continues to be advocated as a key method in hazard identification from whole foods to specific transgenic traits (König et al. 2004). Substantial equivalence is central to risk management in the U.S. for GE crops (NRC 2002) and foods made from them (NRC 2004b).

Substantial equivalence can be applied at any level, from a food (as in the OECD definition above), to a specific genetic trait. In practice, the use of substantial equivalence appears to apply somewhat ambiguously to more than one level, and has "recently...evolved into 'comparative safety assessment"" (NRC 2004b:129). Following this logic, when a new GE crop variety is found to be substantially equivalent to an existing conventional variety, based on specific criteria, then the GE variety is assumed not to constitute a hazard, and therefore, risk management, including risk analysis, would not need to be carried further (NRC 2002:83). This approach has generally supported findings that GE crops are not potential hazards-especially in the U.S., where the focus is on the product and not the process (NRC 2002) - and has been intensely criticized (Schekelaars Biotechnology Consultantcy (SBC) 2001:777, Kok and Kuiper 2003:666). It is seen as a subjective concept masquerading as sound science, which in practice is used to cover up significant differences between conventional and $\mathrm{GE}$ varieties to promote commercialization (GRAIN 2004b). In addition to differences between Third World and industrial agriculture, the current application of substantial equivalence to the Third World appears flawed for three reasons: 1) GE crops may not be substantially equivalent to conventional $\mathrm{MVs}$; 2) if they are substantially equivalent to MVs, then the assumption that MVs are themselves not a hazard may be unjustified; and 3) substantial equivalence focuses on product and ignores process.

First, the finding of substantial equivalence is often 
arbitrary. It is assumed in risk management that GE crops can be compared with conventional varieties in general, and MVs in particular, in terms of a general definition of plant character, and this facilitates a finding of substantial equivalence (NRC 2002:38-39). Domestication is even seen by some as substantially equivalent to genetic engineering (Federoff 2003). However, plant "characters" and "traits" (alternate forms of a character) can be defined at many levels from general to very precise (down to base pairs), and if comparisons are made at more specific levels, transgenes may be substantially different than native genes (Andow and Hilbeck 2004). At a very basic level, for example, most important genes in domestication and development of MVs function by silencing the expression of other genes, whereas many transgenes in GE crops function by expressing new products, such as the cry toxin proteins by $B t$ genes (Gepts 2002).

Second, if it is accepted that GE crops are substantially equivalent to conventionally bred MVs or FVs, the critical assumption that conventional crop varieties are not a hazard may be unjustified (NRC 2002:84-86). Domesticated crops have fueled major biological and social changes for millennia (Harlan 1992, Smith 1995). Conventional modern agriculture and MVs with a small number of novel alleles, including those central to the green revolution, have had widespread and substantial environmental and social effects, e.g., increased pesticide use and increasing yield instability caused by increased genetic uniformity (Matson et al. 1997, Simmonds and Smartt 1999, NRC 2002:21-36, Tilman et al. 2002).

Third, substantial equivalence focuses on the GE plants that are the product of genetic engineering, and not the process of transgenesis that is used to create them (NRC 2002). However, many Third World organizations and farmers, especially indigenous farmers, reject this concept-they feel the process itself violates their cultural rights (CEC 2004, GRAIN 2004b).

\section{Potential Invasiveness of GE Crops and Transgenes}

"Biological invasion" refers to the entrance of an invasive entity into an ecosystem, and the negative consequences of its spread and persistence (Sandlund et al. 1999). The importance of invasive species for ecological and evolutionary processes has been recognized by scientists at least since Darwin (Ludsin and Wolfe 2001), and invasives are an important and growing global problem (Davis 2003).

It is now accepted that genes (or alleles) may also be invasive biological entities (Hindar 1999). For this to occur requires gene flow (the migration of seeds or pollen into a recipient population), hybridization (fertilization between members of distinct populations), and introgression of those immigrant genes into the genome of the recipient population. Evidence suggests that gene flow between crops and their wild relatives is common (Ellstrand 2003b), and that small-scale studies may underestimate gene flow at ecosystem levels (Wilkinson et al. 2003, Watrud et al. 2004). Individual genes may become introgressed even if their relative (individual) fitness is lower than the wild type if gene flow is constant (Ellstrand 2003b).

Invasiveness is a key characteristic considered in assessing GE crops, and the risk management regulations of GE crops in the U.S. are based on those for invasive alien species (NRC 2002). Some GE crop proponents assume that invasiveness can be predicted (e.g., Hancock 2003), but there is also evidence suggesting that prediction is difficult or impossible (Ellstrand 2003b), and depends on the specific context, with spatial and temporal scale critical, and long-term, geographically wide-scale studies required for assessing invasiveness (Kareiva et al. 1996, Shrader-Frechette 2001, Levine et al. 2003, Simberloff 2004).

Both theory (Ellstrand 2003b) and some limited empirical studies (e.g., Hall et al. 2000, Snow 2002a) indicate that GE crops and transgenes can be invasive, and there is no reliable way to predict invasiveness or its consequences and little is known about the movement of conventional or GE crop genes. In addition, the differences in Third World compared with industrial agriculture, where most research has been done, and the lack of data on Third World agriculture, make it even more difficult to predict invasiveness there. Therefore, we conclude that GE crops constitute a hazard in the Third World. The next step in risk management is risk analysis, consisting of estimating the probability of exposure (Potential for Exposure to GE Crops and Transgenes, below), and then of harm from that exposure (Potential Harm Resulting from Exposure to GE Crops and Transgenes, below). 


\section{POTENTIAL FOR EXPOSURE TO GE CROPS AND TRANSGENES}

Although the likelihood of unintended exposure to transgenes from GE crops in Third World is now generally accepted as $>0$ (Nature Biotechnology 2002, Ellstrand 2003b), the way in which it may occur, and thus the potential for harm and treatment, is very different (Fig. 2, see description below) than in industrial agriculture. A fundamental assumption often made by GE crop proponents is that Third World agriculture is primitive and that the major goal of agricultural development is to ultimately replace it with modern industrial agriculture and GE crops, including incorporating farmers into the global seed system dominated by private companies (DeVries and Toenniessen 2001:22-23). As stated by the president of the Rockefeller Foundation when describing the need for a biotechnology revolution for Africa, "While the best answer for Africa may ultimately be to generate other sources of employment for poor farmers, this will not happen overnight. A preliminary step for such a re-sorting of national economies, essential for the survival of those now sequestered on small, unproductive farms, is to improve their production so that they can generate income for food, for health care, for education for their children, and perhaps to begin training for non-farm jobs" (Conway 2003:4).

Based on this assumption, the probability of exposure to and harm from GE crops unique to Third World agriculture will be reduced as it becomes more like industrial agriculture, e.g., farmers will buy seed every year instead of saving their own. However, as discussed above (Seed and Food Systems), there is evidence challenging this assumption, and small-scale, traditionally based Third World agriculture is likely to continue to be important not only for food production, but for conserving crop genetic resources and sociocultural diversity. We focus in this section on exposure of FVs, wild relatives, and cropping systems to GE crop plants [maize in this case] and transgenes (outlined in Fig. 2), and do not discuss exposure of humans or other non-target organisms. We define potential exposure to include seed flow, and pollen flow followed by fertilization (union of gametes that form a zygote). We make the simplifying assumption that transgene flow into a geographic region will initially occur by seed, although this may not always be the case (see Pollen Flow and Fertilization below). Subsequent events (seed germination and growth of a GE maize plant, hybridization between a GE and non-GE plant, introgression of transgenes into a FV population), and their consequences after exposure, are discussed as part of potential harm (Potential Harm Resulting From Exposure to GE Crops and Transgenes).

\section{Seed Flow}

There are typically high levels of gene flow through seed in the Third World (Berthaud et al. 2001, vom Brocke et al. 2003, Pressoir and Berthaud 2004a). Farmers save a high proportion of seed from their own harvests, but often obtain seed through informal seed systems (Ndjeunga 2002), and frequently experiment with new seed (Louette et al. 1997), including planting seed obtained as grain (Cleveland et al. 2004).

International shipments of unsegregated (GE and non-GE) grain can have a major impact on GE seed flow. For example, the U.S., the largest producer of GE crops, exported 42.9 million MT of maize in 2003 , when $40 \%$ of U.S. maize produced was GE and $29 \%$ of the total contained Bt genes (calculated from FAO 2004b, USDA Foreign Agricultural Service (USDA FAS) 2004, USDA NASS 2004). Using the average proportion of the U.S. grain maize production modified for $B t$ from 2000-2003 (22\%, USDA NASS 2004), and an annual average of 5.26 million MT of maize grain imported from the U.S. into Mexico, then during this 4-year period, $\sim 3.3 \times 10^{12} \mathrm{GE} B t$ maize kernels could have been imported annually (calculation based on 1300 kernels/lb (National Corn Growers' Association (NCGA) 2004)). If we assume that $15 \%$ of this imported grain was white maize for human consumption (as it was between 1998-2002 (Zahniser and Coyle 2004)), then about 500 billion kernels of white $B t$ maize entered the Mexican food system annually, or about 5000 kernels/person/year (with an average population of 103 million). In these large-scale movements of grain, some will accidentally escape from grain sacks or trucks, and will be planted, intentionally or unintentionally, where it will germinate, mature, and produce pollen.

A recent report of low levels of transgene contamination in conventional seed of maize and other commodity crops in the U.S. (Mellon and Rissler 2004) suggests another source of exposure: maize seed produced in the U.S. and exported. 
Fig. 2. Informal event tree for identifying potential exposure to crop transgenes in small-scale, Third World agriculture. $\mathrm{GEV}=\mathrm{GE}$ crop variety, $\mathrm{TG}=$ transgene, $\mathrm{FV}=$ farmer variety, $\mathrm{MV}=$ modern variety. Genetic changes and socioeconomic and cultural harm (shaded) are described in event trees in Figs. 3 and 4.

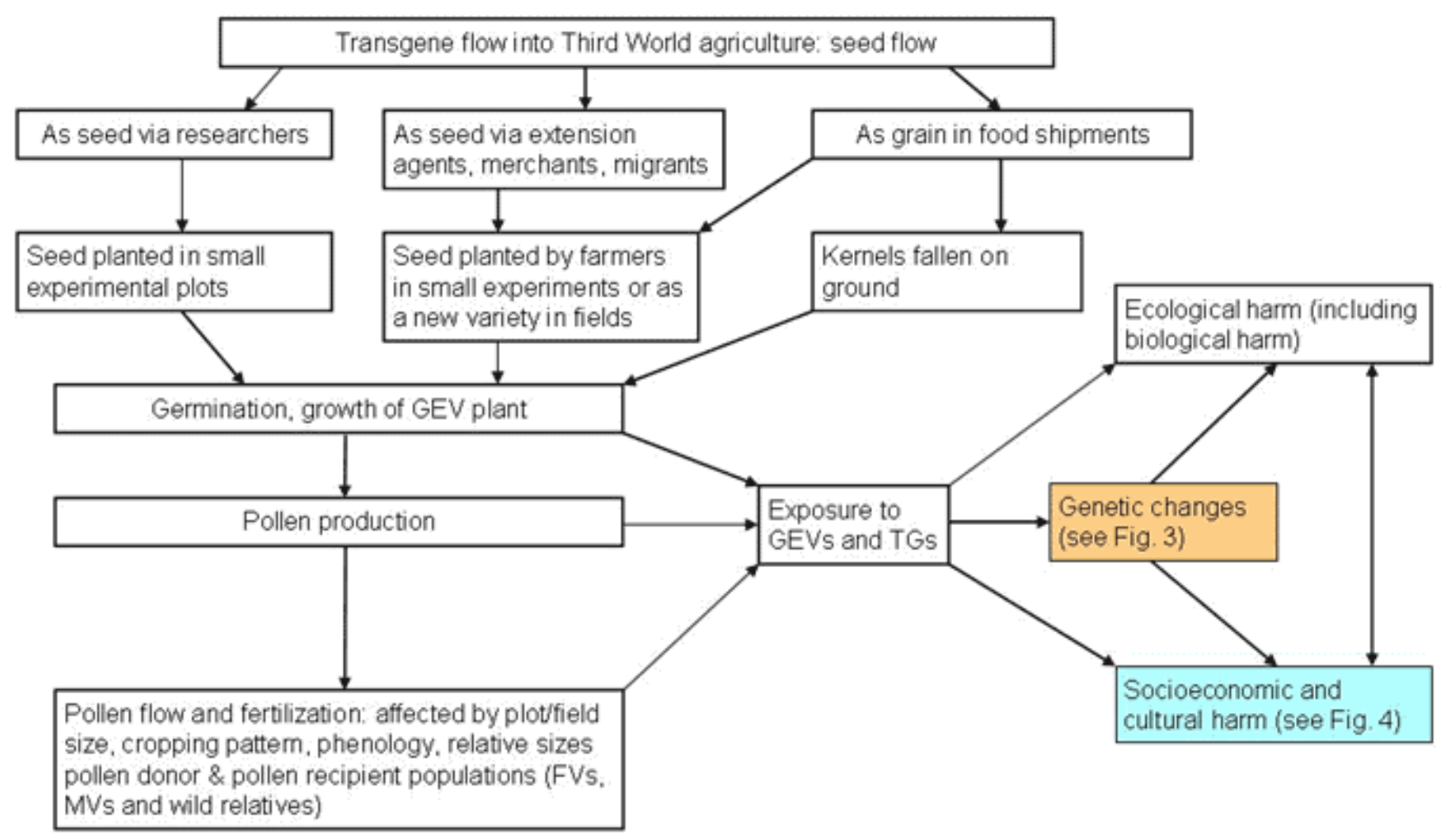

\section{Pollen Flow and Fertilization}

The assumption is often made by GE crop proponents that pollen flow is limited, and therefore, does not pose a risk for Third World farmers (e.g., USAID 2002). However, gene flow through pollen from domestic crop species to wild relatives, and between varieties of a species, can occur over surprisingly long distances (Eastham and Sweet 2002, Ellstrand 2003b, Watrud et al. 2004). Opportunities for unintentional intraspecific transgene flow in Third World agriculture are much greater than in industrial agriculture, where MVs predominate and most seed is purchased each year, especially for hybrid varieties. For example, maize area planted with farmer-saved seed in 1999 was $77 \%$ in Mexico, Central America, and the Caribbean, and $46 \%$ in South Asia (Aquino et al. 2001), compared with $<1 \%$ in the U.S. Farmers may intentionally mix seed from different sources and often have small fields (Louette et al. 1997, Soleri et al. 2003, Pressoir and Berthaud 2004b), increasing the probability of pollen flow between distinct varieties or populations. Phenological asynchrony between FVs and wild relatives and transgenic MVs will likely reduce but not eliminate successful fertilization from this flow (Ellstrand 2003b).

It appears highly probable that pollen containing transgenes will flow to FVs and wild relatives and fertilize these plants, and that these transgenes can persist (Serratos et al. 1997), indeed this has already occurred in Mexico. The public and scientific uproar following the Oaxaca report spurred the Mexican government to sponsor further studies. The Instituto Nacional de Ecología (part of the Secretariat of Environment and Natural Resources, SEMARNAT) and the Comisión Nacional para el Conocimiento y uso de la Biodiversidad (CONABIO) have 
coordinated laboratory work to test these conclusions at the Universidad Nacional Autonoma de México (UNAM) and the Centro de Investigación y de Estudios Avanzados del Instituto Politecnico Nacional (CINESTAV), with results showing transgenes in some FVs in Oaxaca and Puebla (Alvarez-Buylla 2003). The Secretary of Agriculture (SAGARPA) also requested a study in Oaxaca and Puebla, and it shows that transgenes, such as the cry $1 \mathrm{~A} \mathrm{Bt}$ gene are occurring "extensively in landraces throughout the state of Oaxaca" (Alvarez-Morales 2002). These studies have not yet been published and the extent of transgene presence is still disputed, although it is generally accepted that it has occurred. It appears highly probable that transgenes will flow into FVs and other non-GE crop varieties in traditionally based agriculture, as has already occurred with maize in Mexico, as well as into wild crop relatives. The second part of the risk analysis step within risk management is analyzing the potential for this exposure to result in harm.

\section{POTENTIAL HARM RESULTING FROM EXPOSURE TO GE CROPS AND TRANSGENES}

Potential harm resulting from exposure to GE crops and transgenes in the Third World is often assumed to be similar to that in industrial agriculture, but can be very different.

\section{Genetic Change and Ecological Harm}

The ecological impact of transgenes from GE crops in the Third World is just beginning to be empirically investigated, however, genetic theory, genetic and ecological studies of wild plant species, and research on transgenes in industrial agriculture provide useful insights. Here, we focus on genetic changes in FVs and crop wild relatives with potential for causing biological harm that could result in social harm, and only briefly mention other potential effects, such as on non-target species. The extent and actual outcome of the processes described below will, of course, be greatly influenced by the specific transgene, crop species and variety, related species, and biophysical and sociocultural environment, again highlighting the importance of a case-by-case approach to risk management.
As illustrated in Fig. 3, key variables affecting whether biological harm, a form of ecological harm, will occur include 1) volume and frequency (unique or sporadic) of pollen flow ( $m$, migration); 2 ) fitness $(W)$ including relative fitness of different genotypes and absolute (or ecological) fitness of populations; 3 ) selection pressure $(s)$ exerted by biophysical and social environments, including both conscious and unconscious farmer selection; and 4) changes in selection pressures, such as the evolution of resistance in local pest populations or climate change.

Proponents of GE crops tend to make simplifying assumptions about transgene fitness, e.g., that although "neutral" genes may spread they "would have no subsequent impact on fitness," and that transgenes that reduce fitness "will not spread" (Hancock 2003). Population genetic theory predicts much more ambiguous, and potentially significant outcomes, some of which have been confirmed empirically (Ellstrand 2003b). It is important to differentiate relative fitness of genotypes within a population, which determines whether alleles will spread, from absolute fitness of a population, which determines whether the population will shrink or grow, i.e., become invasive (Bergelson and Purrington 2002). If the transgene confers high relative fitness in local selection environments compared with other genotypes, that transgene will likely sweep through the population, and can become established in that population. However, high relative fitness within the population can be coupled with reduced absolute fitness of the recipient population comparison with other populations in the environment, leading to reduction or disappearance of the population, and a loss of genetic diversity (Endler 1986:43-44, Bergelson and Purrington 2002).

The fate of native resistance alleles in the presence of transgenes with superior relative fitness, e.g., a $B t$ transgene, could be a concern if transgene fitness is high but temporary (non-durable) as when evolution of resistance occurs in pest populations (see Fig. 3). Although the actual dynamics of such a process are complex and difficult to predict (Medvinsky et al. 2004), they may be particularly important for Third World agriculture. For example, introgression of a transgene with high relative fitness into local $\mathrm{FVs}$ could reduce selection maintaining native resistance alleles, potentially leading to a decrease in their frequencies, or even 
Fig. 3. Informal event tree for identifying potential genetic changes and resulting harm (shaded) from crop transgenes in small-scale, Third World agriculture. GEV = GE crop variety, $\mathrm{TG}=$ transgene, $\mathrm{FV}=$ farmer variety, $\mathrm{WR}=$ crop wild relative, TGFV = transgenic farmer variety, TGWR = transgenic crop wild relative, $\mathrm{W}=$ fitness (relative fitness, unless otherwise indicated), $\mathrm{m}=$ migration rate, $\mathrm{s}=$ selection pressure.

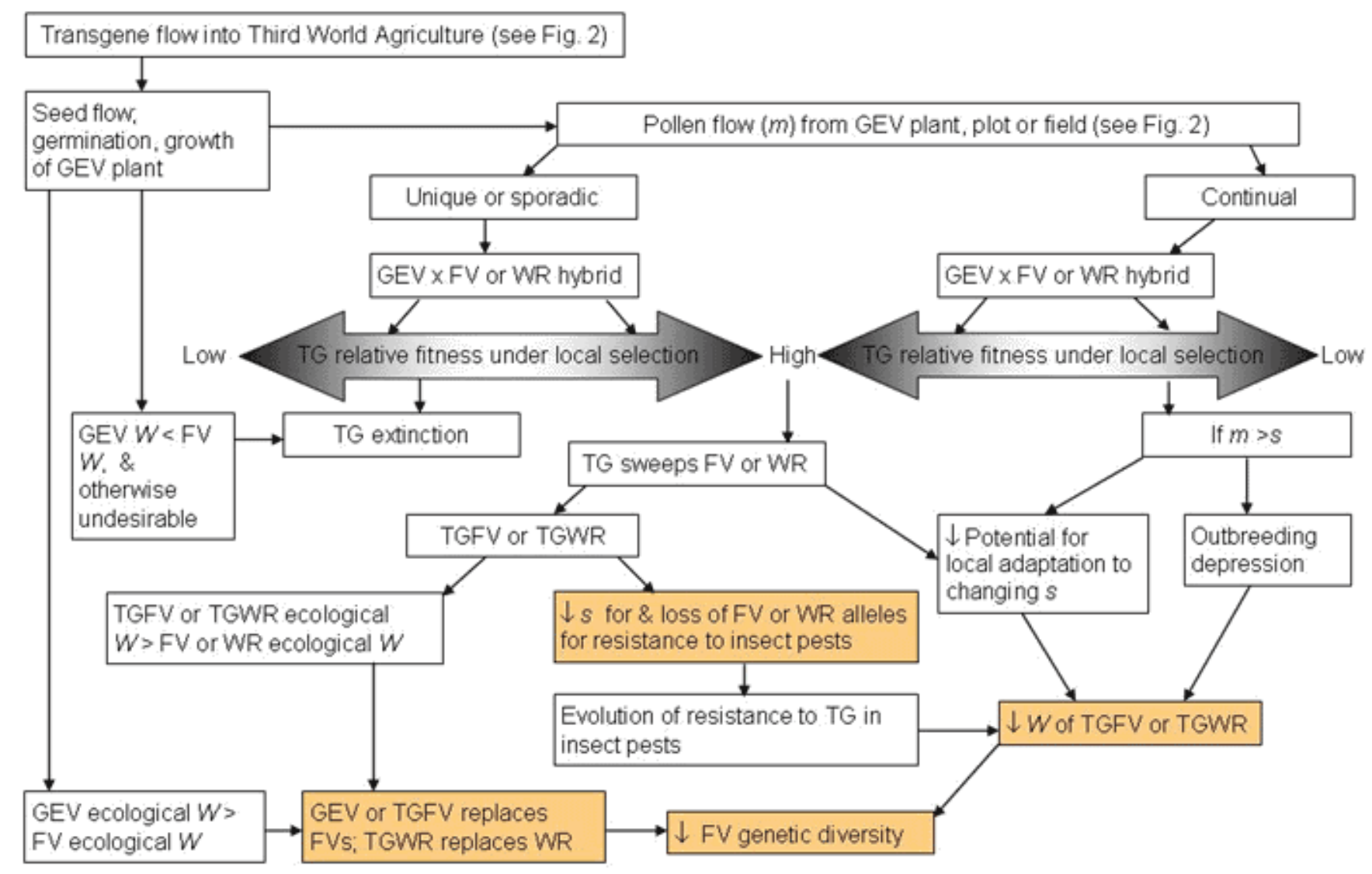

their loss (Soleri, unpublished manuscript Simulating the genetic consequences of relaxing selection for horizontal resistance in low resource farmers' crop populations). If the transgene's fitness declines, as could occur with $B t$ given the presence of $B t$-resistance alleles in pest populations (Andow et al. 2002, Burd et al. 2003, Génissel et al. 2003), a worst-case scenario suggests farmers may be left with a transgenic FV that is less pest resistant than their original FV. Another possibility is that loci tightly linked to the transgene will lose variation, reducing FV ability to adapt (Bergelson and Purrington 2002), and therefore, increasing probability of varietal loss. Even when a transgene reduces relative fitness compared with native FVs or wild relatives without that transgene, it can still spread in a population through gene flow if it is linked to alleles contributing to an overall greater fitness. If relative fitness of a GE variety $\mathrm{x} F \mathrm{FV}$ or GE variety $x$ wild relative hybrid is less than that of the native FV or wild relative genotypes, and gene flow is continual so that $m$ is greater than $s$, harm can still result, in the form of decreasing the population's capacity for ongoing local adaptation to changing selection forces, or as outbreeding depression, lowering the absolute fitness of the recipient population (Ellstrand 2003b).

Biological harm could result when genetic changes reduce absolute fitness of FVs or wild crop relatives, leading to severe reductions in population size or extinction (Ellstrand 2003b,, 2003a). On the other 
Fig. 4. Informal event tree for identifying potential socioeconomic and cultural harm resulting from crop transgenes in small-scale, Third World agriculture. Shaded $=$ some major forms of potential harm. IPRs = intellectual property rights, $\mathrm{GEV}=\mathrm{GE}$ crop variety, $\mathrm{TG}=$ transgene, $\mathrm{FV}=$ farmer variety, $\mathrm{WR}=$ crop wild relative, $\mathrm{TGFV}=$ transgenic farmer variety, $\mathrm{TGWR}=$ transgenic crop wild relative, $\mathrm{W}=$ fitness (relative fitness, unless otherwise indicated), $\mathrm{s}=$ selection pressure.

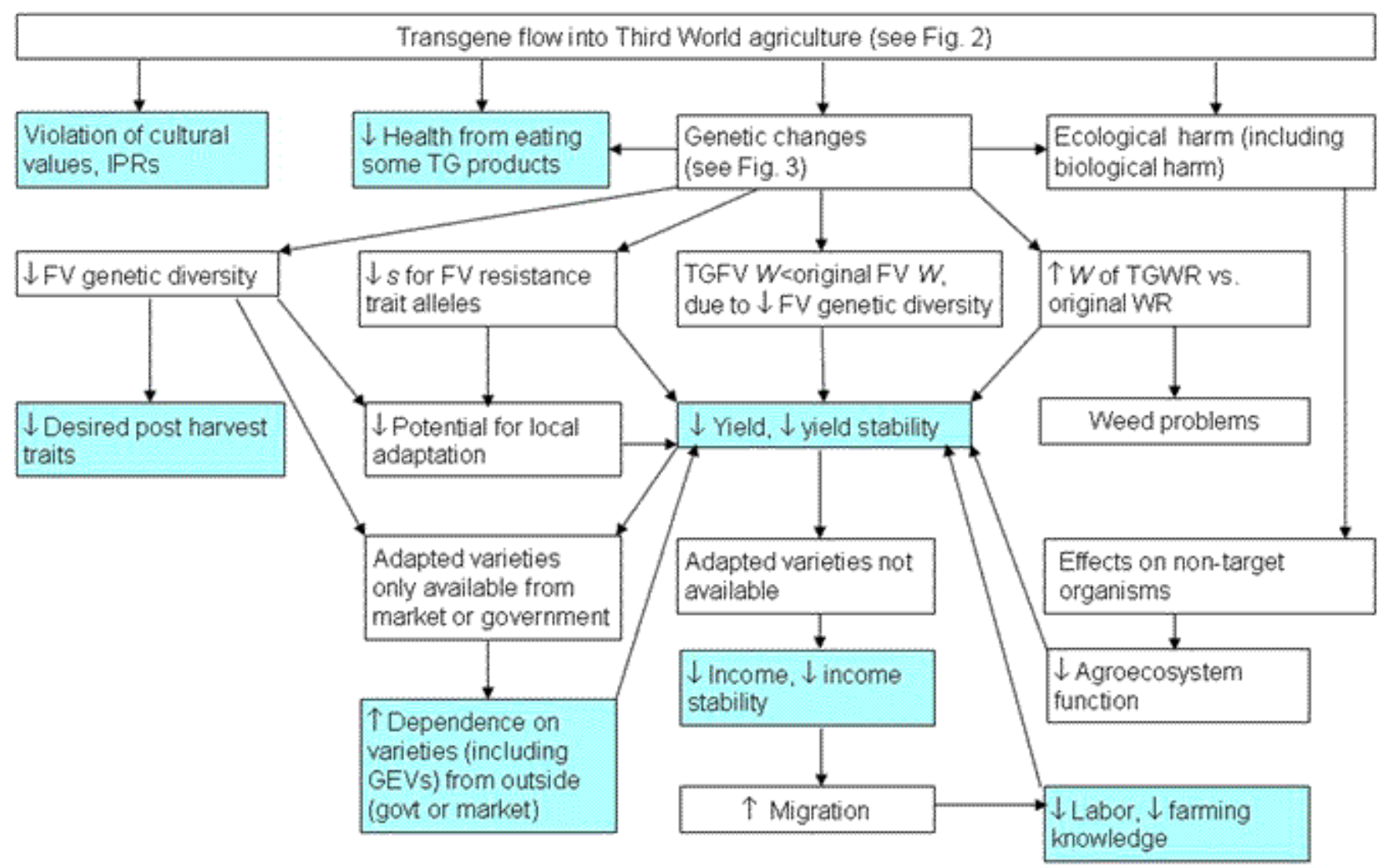

hand, if the absolute fitness of a GE crop variety, transgenic FV, or transgenic wild relative is greater than other FVs or wild relatives, the former may become invasive, replacing FVs or wild relatives and decreasing genetic diversity, or it may contribute to increasing weediness in wild relatives (Bergelson and Purrington 2002).

Another possibility not included in Fig. 3 is that any plant containing a transgene could have harmful effects on non-target species directly (e.g., pesticidal transgenes) or indirectly (e.g., through invasiveness), and such effects are difficult to generalize and predict (Andow and Hilbeck 2004).

\section{Socioeconomic and Cultural Harm}

In this section, we focus on socioeconomic (hereafter "social") and cultural harm as a result of genetic change to FVs and wild relatives, and its ecological effects (Fig. 4), for example a reduction in crop yield and yield stability. This could, in turn, cause social harm in the form of reduced income and income stability, leading to short-term remedial actions that compromise longer-term survival (Hardaker et al. 1997). Decreased yield and yield stability could also contribute to increased dependence of farmers on MVs from the formal seed system, which can increase long-term instability if that system is unreliable or if farmers are unable to purchase seed when needed (Cromwell et al. 1993). 
Similarly, loss of varietal diversity could also increase dependence on outside seed sources, and may result in loss of locally important agronomic and post-harvest consumption traits-reasons given by farmers for retention of their local FVs despite availability of MVs (e.g., Perales et al. 1998).

In addition to potential social harm as a result of genetic change, varieties of GE maize being developed will produce pharmaceutical and industrial compounds commercially, with greater potential for harm to human health-the probability of exposure through gene flow will be much lower because of stricter confinement policies, but the probability of harm much greater (Ellstrand 2003c, UCS 2003). Social harm could also result from the violation of cultural values and intellectual property rights of farmers (Soleri et al. 1994, Hickey and Mittal 2003). This perception among some indigenous communities in Mexico as stated the recent CEC report (CEC 2004:16) was criticized by the U.S. government, apparently because it was seen as a minority value and because it did not have a scientific basis (CEC 2004:51).

\section{EVALUATING RISK}

Evaluation of risk (i.e., exposure $\mathrm{x}$ harm) in Third World agriculture will require not only discussing GE crops per se with farmers, but potential harm as well. This will require representing potential biological and social harm as accurately as possible in ways that farmers can understand. To do this, we have successfully used interview scenarios based on fundamental biological principles and farmers' own experiences, which present situations for farmers' assessment that are in some way novel to the farmers (Soleri and Cleveland 2005). We have begun the process of including Third World farmers in evaluation of GE crops using scenarios that translate potential harm identified through informal event tree analysis into situations that farmers can understand (Soleri et al. 2003, Cleveland et al. 2004).

In research we are conducting with colleagues in six communities in Mexico, Guatemala, and Cuba, most $(66 \%)$ farmers interviewed (323) felt the process of transgenesis per se in maize was acceptable-although this varied significantly between communities (Cleveland et al. 2004). These data reflect one element of risk evaluation- harm to cultural values - but not farmers' overall evaluation of risk from GE maize, which may be different. Similarly, the internal combustion engine per se was judged acceptable by industrial society, but its institutional associations and consequences are now seen as unacceptable by many members of those societies. Therefore, we used a scenario to elicit farmers' evaluations of possible social and biological changes from current GE crop varieties, specifically $B t$ maize, but without mentioning GE crops.

Figures 5 and 6 illustrate this scenario about potential changes (based on the event tree in Fig. 4) in yield stability and seed procurement, that could result from the evolution of pest resistance to $B t$ maize. The scenario-presented to farmers using bags of grain as visual aids - describes two varieties that differ only in their long-term yield performance, seed source, and cost. The two types of varieties are described, but never identified as transgenic or FV, simply as varieties of maize, and farmers asked to choose the variety best for them. Varieties $\mathrm{X}_{1-\mathrm{n}}$ represent a series of varieties whose properties simulate $B t$ maize varieties. These varieties have much higher yields than variety $\mathrm{Z}$ when first planted, because their insecticidal properties alleviate major production losses. However, because of the evolution of pest resistance to that transgene, yield falls, so that to maintain high yields one $\mathrm{X}$ variety has to be periodically replaced by a new one purchased from the formal seed system. In contrast, variety $\mathrm{Z}$ has a low but stable yield, and farmers obtain seed from their own harvest, from other farmers, or in local markets.

Most farmers interviewed (86\%) preferred the more stable, low-yielding, locally available variety $\mathrm{Z}$, suggesting they were not willing to accept the potential consequences of using GE crops in their fields as illustrated in this scenario. These results challenge one of the key assumptions in risk management for Third World agriculture, that farmers will adopt higher-yielding transgenic MVs, even though they may also have greater yield instability and require at least occasional reliance on the formal seed system. The scenario is relevant for discussion of transgenes introduced into $\mathrm{FV}$ backgrounds as well because, even in FVs, pesticidal transgenes that confer superior fitness and spread through local populations may exert selection pressure, resulting in pest resistance. At that point, the formal seed system may be the only 
Fig. 5. An example of scenarios presented to farmers to elicit their evaluation of potential harm from GE crop varieties and transgenes. We wanted to know which farmers value more: a) stable, but lower-yielding varieties from local, inexpensive seed sources, or b) more expensive but responsive, initially higher-yielding varieties from the formal seed system, with declining yields (as is the potential with insecticidal $B t$ maize varieties to which pests evolve resistance). We verbally presented this scenario for farmers' evaluation, using bags of grain as visual aids. When yields of X1 drop, it could be replaced with a new variety (X2) through the formal seed system in towns or cities. We asked, "Which variety would you choose for sowing in your fields?" Null hypothesis: There will be no difference in farmers' choices.

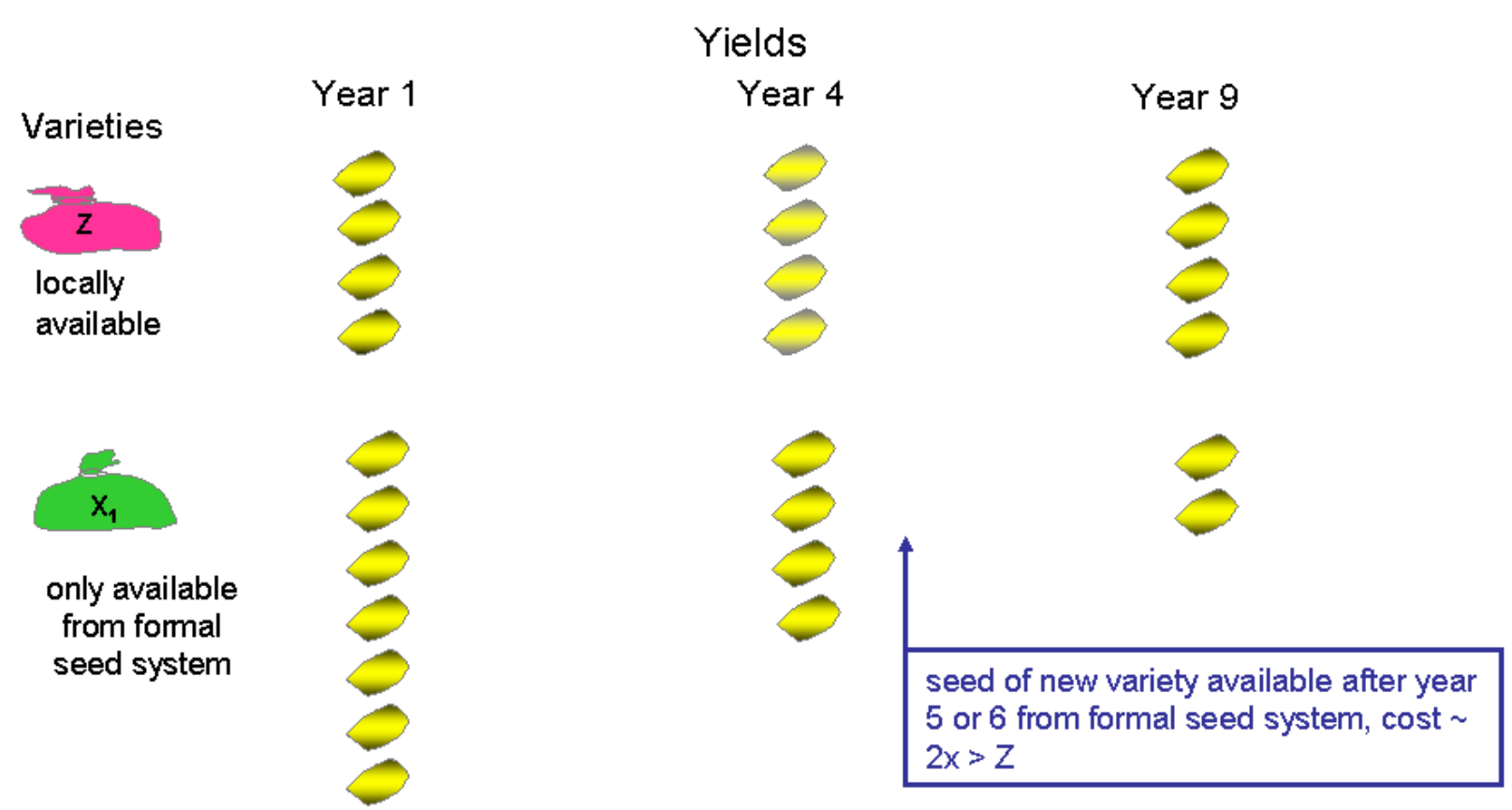

Bags of grain representing units of harvest being depicted

source for obtaining an effective alternative transgene.

These results demonstrate the necessity as well as the complexity of including farmers in the evaluation stage of risk management. Although the assumption of some GE opponents that all Third
World farmers find the process of transgenesis culturally unacceptable is not supported, neither is the assumption by some proponents that farmer acceptance of transgenesis means they view GE crops positively. The process, the product, and its consequences are all important in evaluation. The possible consequences of using a GE crop (Bt 
Fig. 6. Graphic representation of Fig. 5 scenario for discussion with collaborating scientists.

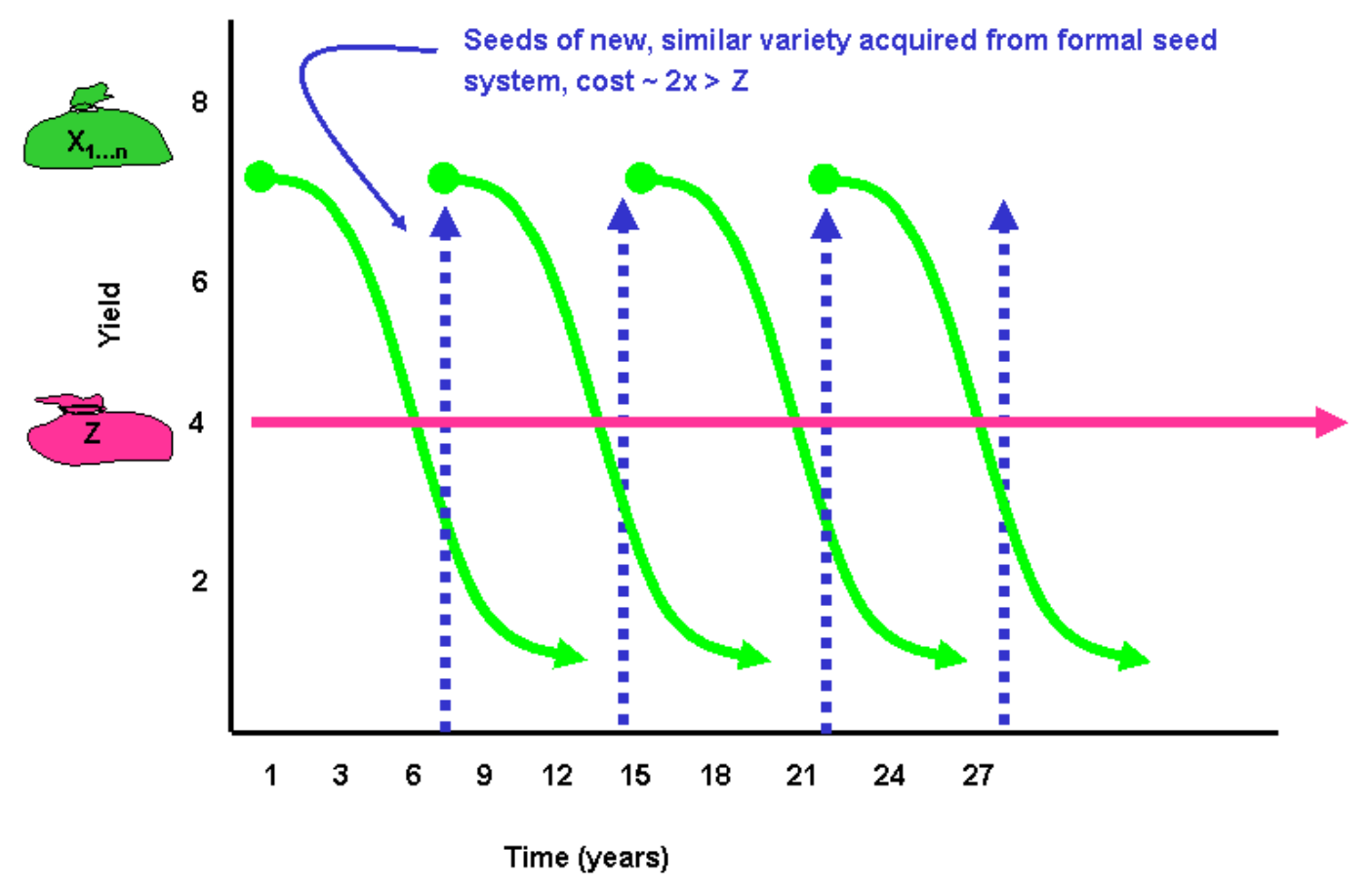

maize) were not acceptable to an even larger majority than that which found transgenesis acceptable. These results clearly show that great care must be taken in interpreting farmers' identification of cultural harm and its implication for risk management and policy. They also indicate the need for discussion about how heterogeneous values regarding GE crops, agriculture, and society will be considered and accommodated.

\section{RISK TREATMENT}

Strategies being developed and applied to treat risks posed by GE crops and transgenes in industrial agriculture are, in many cases, inappropriate for the Third World, as we outline below, using some examples of treatment approaches for evolution of resistance in agricultural pests controlled by GE crops. 


\section{Reducing Potential for Exposure}

As a result of public alarm and scientific uncertainty about the effects of GE crops, their containment (prevention of gene flow) has been advocated (Nature Biotechnology 2002). Increasingly, complete containment is seen as being physically impossible, and confinement (minimization of gene flow) is seen as the most realistic goal (Snow 2002b, NRC 2004a). The recent NRC report recommended that confinement methods be tested in "any environment that the GEO could be foreseen to occupy" and that this included "other countries to... which GEOs are likely to move" (NRC 2004a:183, 194). Current isolation requirements are inadequate for complete control of pollen flow (NRC 2002:125, Rieger et al. 2002), and complete control may be economically nonviable even in industrial countries (Smyth et al.2002). Thus, there is a growing demand for molecular gene flow control mechanisms integrated into transgenes (Nature Biotechnology 2002), and although progress is being made on a number of different strategies, they are not ready for application, and may bring with them their own problems (Daniell 2002), including violation of farmers' cultural and intellectual property rights (Snow 2002b, United Nations Environment Programme 2002, NRC 2004a)

The assumption is sometimes made by proponents of GE crops that exposure to transgenes through gene flow in the Third World can be controlled through farmers' selection (e.g., AgBio View 2002). This is based on further untested assumptions that transgenes are similar to the other genes on which farmers have exerted selection pressure over long periods (6000 years for maize), and that farmers see selection as a means to change their crop populations, that is achieve genetic response. However, transgene function differs from that of most genes selected for in domestication (Gepts 2002); the domestication syndrome in many crops is the result of a limited number of traits controlled by relatively few genes or quantitative trait loci, yet even for qualitative traits, it appears to have taken farmers many generations to fix desirable alleles (Buckler et al. 2001, Jaenicke-Després et al. 2003); and, over the short term, farmers' maize selection seems to be operating on a very few alleles with frequencies at most loci unaffected by farmers' direct selection (Louette et al. 1997, Pressoir and Berthaud 2004a, 2004b, Soleri and Cleveland 2004). In fact, farmers are aware of the difficulty of achieving genetic response to selection for many quantitative traits under their conditions and often do not see selection as a means to change their crop populations. Instead, they seek high $s$ values, even while accepting $R=0$ ( $R$, genetic response to selection), as a means to ensure seed quality instead of obtaining population genetic change (Soleri et al. 2000). The case of sugar beet $x$ sea beet hybrids in Europe demonstrates that farmers may not be able to economically control unwanted gene flow even with the resources available in industrial countries (Ellstrand 2003b).

\section{Reducing Potential for Harm}

In areas adopting GE crops, the main method advocated for avoiding resistance evolution is combining high-dose GE varieties (producing sufficient toxin to kill nearly all heterozygous pest larvae, Fitt et al. 2004:225), with planting refuges of non-GE crops. Some GE proponents suggest that "pest-resistant GE crops are easy to manage at the farm level" with no mention of refuge requirements or the effects of resistance evolution (Qaim and Zilberman 2003:901). However, there are reports of widespread breaches of refuge requirements in the U.S., especially among smaller farms (calculated in Jaffe 2003b, 2003a, based on USDA NASS 2003), and in Third World countries (Jayaraman 2002). In part, these breaches appear to be caused by the economic penalty incurred by individual compliant farmers, who are encouraged to cheat by the lack of workable compliance monitoring and punitive mechanisms. In addition, there has been pressure to reduce the size of refuge required, e.g., U.S. federal requirements for refuges for a $B t$ maize variety effective against root worm were halved in May 2003, due to industry and farmer demands (Powell 2003), from expert panel recommendations of $50 \%$ to $25 \%$ of area sown. For most low-resource Third World maize farmers, field size is so small (Growing Environments and Genotypes, above) that refuges would not work for many reasons, including the contamination-and thus reduced efficacy-of nearby refuge plantings by transgene flow (Chilcutt and Tabashnik 2004). The effectiveness of seed mixtures (GE and non-GE) to slow resistance evolution (Fitt et al. 2004) may be reduced for the same reason. Alternative approaches for creating a more effective and practical refuge strategy for such agricultural systems have been outlined (Gould and Cohen 2000), but both social and biological difficulties were deemed substantial. 
Another recommended strategy is periodic genetic testing of pest populations to monitor and respond to resistance evolution (Gahan et al. 2001), contributing to an adaptive management approach. Yet monitoring may be very difficult in the Third World, where there are few resources for extension and other support services implementing monitoring for evolution of resistance in pest populations in response to pesticidal GE crops. For example, $<3 \%$ of farms in Oaxaca receive any public or private technical assistance for agriculture (INEGI 2001), and in one community where we are working, $<0.3 \%$ receive this support. Additionally, the cost of such monitoring-one minimum estimate is $\$ 500 /$ field sampled in the U.S. (Fitt et al. 2004:241) —is itself prohibitive for such systems (Conway 2003:15).

The inappropriateness for Third World agriculture of many risk treatment strategies proposed for GE crops in industrial agriculture suggests that effective treatment requires attention to the contexts of Third World agriculture, beginning with decisions about what kinds of crop varieties, including but not limited to GE varieties, would best meet farmers' goals (Gould and Cohen 2000; Snow et al. 2004).

Yet, at the same time that variety development, risk treatment, and the whole risk management process needs to be appropriate for each location in the Third World, the problem of risk management is necessarily a global one, and complete containment is not possible regardless of regulations, as in the case of GE maize in Mexico. One solution to this problem proposed by proponents of GE crops has been clearly stated by the president of the Rockefeller Foundation:

For the developing countries, particularly the poorest, the need to assure the safety of biotech products poses seemingly insurmountable problems, since most of these countries do not have testing and regulatory systems that would meet our consumer standards, nor can they afford to develop them. The cost of testing and regulation affects price, and the price of food affects the hungry. If resource-poor governments must spend $\$ 20$ million to ensure that a new product is safe for each ecological setting in which it may be used as is routinely the case with pharmaceuticals new products will never reach the poor. I do not mean to imply that safety is a luxury poor countries cannot afford. Quite the opposite. Globalization means that the safety of one is now the safety of all. I mean that if safety requirements are not to inflate the price of food out of the reach of the poor, new strategies for institutional management and sharing of scientific and technological capabilities will be required.Conway (2003:15)

The implication is that poor Third World countries should accept a risk management process developed in the industrial world, which we have shown above to be questionable. Based on our rethinking of the risk management process, identification of what constitutes the minimum acceptable level of "safety for all" requires recognition of the ways in which Third World agricultural systems differ from industrial ones, and their importance for food production, and conservation of social, cultural, and genetic diversity. Safety for all will be most efficiently and democratically defined if both proponents and opponents of GE crops explicitly identify their assumptions and consider both empirically supported facts about those systems and the subjective assessments of Third World farmers and consumers. This might require changes in the industrial world to increase safety in the Third World, such as ending development of GE pharm or industrial chemical maize, as advocated by some scientists (CEC 2004:20, UCS 2003). Working on ways to improve the risk management process for GE crops is a valuable task, including identification of characteristics and processes indicating when generalizations are or are not appropriate. Improving risk management will also provide important insights as we begin consideration of other new technologies with broad implications, such as nanotechnology.

\section{CONCLUSIONS}

1. Necessity for a Third World farmer perspective in the risk management process for $G E$ crops. Conclusions that genetically engineered (GE) crops and transgenes pose no risks for Third World farmers are often based on untested assumptions about both GE crops and Third World farmers. From the limited information available now, it appears that the risk management process for GE crops in the Third World poses different, and often more complex, challenges than in industrial agricultural systems. Although the same biological principles apply, the small field and farm size, seed and food systems integrated at the household level, genetically 
open seed systems, lack of resources, and poverty in the Third World contribute to the contrast with the industrial world and the complexity of risk management. Ultimately, the net effect of GE crops can only be determined by assessing benefits as well as costs (risk), and comparing them with conventional modern varieties (MVs), and farmers' traditional varieties (FVs), and alternatives such as transgenic FVs and organic varieties. However, a rigorous, objective, risk management process needs to be carried out for specific locations in the Third World for specific GE crops before comparative benefit-cost analysis can be carried out. This seems the best way to increase the probability that farmers will be protected from potential risks of GE crops, and will enjoy their potential benefits.

2. Methods. Empirical data are not now available for estimating numerical probabilities of exposure and harm or for designing appropriate risk treatment, nor do mechanisms exist for meaningful farmer participation. Therefore, carrying out the risk management process in the Third World requires identifying potential issues and indicating needed research, and event trees are useful tools for this. In addition, explicit differentiation of facts and values (including assumptions about the goals of agricultural development) is needed to facilitate more balanced and productive participation by representatives of different interests, including Third World farmers and consumers.

3. Determining if a GE crop variety is a hazard. Risk management findings that GE crops do not constitute a hazard in the industrial world cannot be extended to the Third World because conditions are very different. Substantial equivalence as currently used is an inappropriate method of judging hazardousness because it is controversial and often arbitrary, and even if GE crops are judged to be substantially equivalent to conventional MVs, MVs themselves are a hazard in the Third World. Additionally, the focus on the end product in the concept of substantial equivalence ignores the possibility that GE crops might be judged a hazard based on the processes used to create or disseminate them. Finally, GE crops are potentially invasive, and potential invasiveness is very difficult to judge, especially in the Third World for which there is much less data.

4. Risk analysis. Potential for exposure to GE crops and resulting harm in the Third World is much different than that in industrial countries. In the case of GE maize flowing from the U.S. to Mexico for example, potential exposure pathways are many, with some differing substantially from exposure in industrial agricultural systems. Potential genetic changes in FV and wild relative populations as a result of exposure depend on the complex interaction of gene flow rates, relative and absolute fitness, and selection coefficients, all of which are difficult to predict, and will require detailed, site- and species-specific research. However, the range of potential genetic changes could lead to ecological-including biological-harm, which in turn could cause social harm. Much of this harm is not specific to GE crops, but may be exacerbated by them, for example the social and ecological harm caused by MVs as part of the green revolution (in addition to the benefit of increased yields). Absence of one form of harm does not render GE crops harmless. Thus, care must be taken in interpreting farmer identification of different forms of harm, e.g., a technology per se being culturally acceptable, but its potential consequences seen as unacceptable.

5. Risk evaluation. Farmers should and can be included in evaluation, for example through research collaboration with scientists, and this can make important contributions to risk management. New approaches (such as the scenarios we are currently using) are needed so that farmers can evaluate GE crops' potential for harm, something those farmers would not otherwise be able to do. Evaluating the results of risk analysis will be extremely difficult until key assumptions are made explicit, and the distinction between 
objective (empirically verifiable) and subjective (beliefs, values) statements is made. Only if this is accomplished can balanced evaluation recognizing the importance of both objective and subjective aspects proceed.

6. Risk treatment. Many measures proposed for treating potential risks of GE crops in the industrial world are not appropriate for the Third World. In terms of reducing exposure, adequate bioconfinement technologies are not yet available, they will be expensive and probably never complete, and assumptions that farmers can control undesirable gene flow are unfounded. Reducing harm has many of the same problems, e.g., slowing evolution of resistance in pests through refuge plantings, and adequate monitoring programs would be very costly and difficult to implement given the resources and structure of Third World agriculture. Reducing potential risk may also require policy changes in industrial agriculture, e.g., segregating GE and non-GE grain exported to the Third World, as with the export of maize grain to Mexico.

7. Research needs. Current scientific knowledge of GE crops and transgenes, and Third World agriculture is inadequate for a thorough risk management process. In addition to more research on transgenes in the lab, experimental plot, and industrial agricultural field, creative research in collaboration with farmers is required to understand the unique potential of transgenes from farmers' perspectives in their environments, including potential harm to key attributes for the functioning of Third World agricultural systems, e.g., open seed systems and broadbased resistance of FVs to environmental stress. Finally, research contributing to improvement of the risk management process will need to be followed by research for and application of benefit-cost analyses that include GE crops, non-GE MVs and FVs, and alternative crop varieties (e.g., organic varieties and transgenic FVs).

\section{SPECULATION}

1. Comparative benefit-cost analysis. There may be potential long-term benefits of GE crops for Third World farmers. However, these benefits are unlikely to be achieved unless development and introduction of GE crops are based on the unique characteristics of these systems (Gould and Cohen 2000) and farmers, and includes their knowledge and values. Any such benefits need to be compared with the benefits and costs of alternatives to GE crops.

2. Future GE crops. Soon to arrive pharmaceutical and industrial chemicalproducing GE crops pose significantly greater risks for Third World agriculture because of their greater potential harm. For example, in light of massive GE maize seed flow into Mexico, where maize is the staple food of millions of small-scale farmers, the potential for significant harm from pharmaceutical or industrial chemicalproducing maize is great.

3. GE crops and the risks of agriculture in general. The biological and social risks that modern industrial agricultural systems carry (Matson et al. 1997, Vitousek et al. 1997, Tilman et al. 2002) may be exacerbated, as well as mitigated, by GE crops. For example, inadequate appreciation of the potential risk of conventional MVs has meant that increases in crop yield and food availability have been accompanied by very significant biological and social harm (NRC 2002). Therefore, to the extent that GE crops contribute to or ameliorate the system level risks posed by industrial agriculture in general (e.g., Andow $2003 \mathrm{~b}$ ), these risks need to be analyzed in risk management and comparative benefit-cost analysis for GE crops.

4. GE crops and privatization of agricultural resources. There may be a fundamental incompatibility between science for private profit and science for social good that requires 
balancing by means of social controls, not markets (Shorett et al. 2003), as has been suggested for controlling invasive alien species (Perrings et al. 2002). Therefore, the increasingly private and concentrated control of agriculture, including plant breeding and transgenic technologies and GE crops (Frey 1996, Graff et al. 2003), may itself be a hazard, and the potential harm posed by this socioeconomic structure to the process of achieving sustainable agriculture globally should be included in risk management for GE crops.

5. Risk management process and social consensus. To reach broader social consensus, risk management will need to encourage discussion of underlying values of those with different perspectives on GE crops. Risk management will never achieve its goal of creating social consensus (NRC 1996) if people continue to discuss superficial reasons for disagreement, or dismiss all value-based statements other than their own.

Responses to this article can be read online at:

http://www.ecologyandsociety.org/vollo/iss 1/art9/responses/

\section{Acknowledgments:}

We thank the many farmers we have worked with, especially the farmers of Oaxaca, Mexico, who have helped us learn about their farming with patience and good humor; Flavio Aragón Cuevas, our collaborator in field research in Oaxaca; Mario $R$. Fuentes Lopez and Humberto Ríos Labrada, our collaborators in Guatemala and Cuba; Norm Ellstrand, Carla D'Antonio, Paul Gepts, and Jim Coors for discussion and comments on portions of previous versions of this paper; Garry Peterson, the Ecology and Society subject editor and three anonymous reviewers for the journal. We thank the University of California, Santa Barbara Faculty Senate, Wallace Genetic Foundation, and NSF (SES-9977996, DEB-0409984) for funding part of the research on which this article is based. We alone are fully responsible for the contents, including any errors or misinterpretations.

\section{LITERATURE CITED}

AgBio View. 2002. Joint statement in support of scientific discourse in Mexican GM maize scandal. (Online.) URL:

http://www.agbioworld.org/jointstatement.html.

Alvarez-Buylla, E. 2003. Ecological and biological aspects of the impacts of transgenic maize, including agro-biodiversity. Prepared for the Secretariat of the Commission for Environmental Cooperation of North America, as part of the Article 13 Initiative on Maize and Biodiversity: the Effects of Transgenic Maize in Mexico. (Online.) URL:

http://www.cec.org/files/pdf//Alvarez-Buylla-e.pdf

Alvarez-Morales, A. 2002. Transgenes in maize landraces in Oaxaca: official report on the extent and implications. Seventh International Symposium on the Biosafety of Genetically Modified Organisms, 10-16 October 2002, Beijing, China. (Online.) URL:http://www.worldbiosafety.net/

Andow, D. A. 2003a. Negative and positive data, statistical power, and confidence intervals. Environmental Biosafety Research 2:1-6.

Andow, D. A. 2003b. UK farm-scale evaluations of transgenic herbicide tolerant crops. Nature Biotechnology 21:1453-1454.

Andow, D. A., J. A. Hagen, and G. S. Robinson. 2002. Resisting resistance to Bt-corn. Pages 99-124 in D. K. Letourneau and B. Elpern Burrows, editors. Genetically engineered organisms: assessing environmental and human health effects. CRC Press, Boca Raton, Florida, USA.

Andow, D. A., and A. Hilbeck. 2004. Sciencebased risk assessment for nontarget effects of transgenic crops. BioScience 54:637-649.

Aquino, P., F. Carrión, R. Calvo, and D. Flores. 2001. Selected maize statistics. Pages 45-57 in P. L. Pingali, editor. CIMMYT 1999-2000 World maize facts and trends. Meeting world maize needs: technological opportunities and priorities for the public sector. CIMMYT, D.F., Mexico.

Aragón Cuevas, F. 1989. El maíz en Oaxaca, variabilidad genética y distribución. Thesis. Centro de genética del Colegio de Postgraduados, Montecillo, DF, Mexico. 
Aragón Cuevas, F. 1995. La produción de maíz en Oaxaca, situación actual y perspectivas futuras. INIFAP Pacifico Sur, Oaxaca, Oaxaca, Mexico.

Bau, H. J., Y. I. H. Cheng, T. A. Yu, J. S. Yang, and S. D. Yeh. 2003. Broad-spectrum resistance to different geographic strains of Papaya ringspot virus in coat protein gene transgenic papaya. Phytopathology 93:112-120.

Bergelson, J., and C. B. Purrington. 2002. Factors affecting the spread of resistant Arabidopsis thaliana populations. Pages 17-31 in D. K. Letourneau and B. Elpern Burrows, editors. Genetically engineered organisms: assessing environmental and human health effects. CRC Press, Boca Raton, Florida, USA.

Berthaud, J., J. C. Clément, L. Emperaire, D. Louette, F. Pinton, J. Sanou, and S. Second. 2001. The role of local-level gene flow in enhancing and maintaining genetic diversity. Pages 1-23 in H. D. Cooper, C. Spillane, and T. Hodgkin, editors. Broadening the genetic base of crop production. CABI, Wallingford, UK.

Birch, A., R. Wheatley, B. Anyango, S. Arpaia, D. Capalbo, E. Getu Degaga, D. E. Fontes, P. Kalama, E. Lelmen, G. Lovei, I. S. Melo, F. Muyekho, A. Ngi-Song, D. Ochieno, J. Ogwang, R. Pitelli, T. Schuler, M. Sétamou, S. Srinivasan, J. Smith, N. Van Son, J. Songa, E. Sujii, T. Q. Tan, F.-H. Wan, and A. Hilbeck. 2004. Biodiversity and non-target impacts: a case study of Bt maize in Kenya. Pages 117-185 in A. Hilbeck and D. A. Andow, editors. A case study of Bt maize in Kenya. CAB International, Wallingford, UK.

Borlaug, N. E. 2000. Ending world hunger. The promise of biotechnology and the threat of antiscience zealotry. Plant Physiology 124:487490.

Brown, A. H. D. 1999. The genetic structure of crop landraces and the challenge to conserve them in situ on farms. Pages 29-48 in S. B. Brush, editor. Genes in the field: on-farm conservation of crop diversity. Lewis Publishers, Boca Raton, Florida, USA; International Plant Genetic Resources Institute (IPGRI), Rome, Italy; International Development Research Centre (IDRC), Ottawa, Ontario, Canada.

Buckler, E. S., IV, J. M. Thornsberry, and S.
Kresovich.2001. Molecular diversity, structure and domestication of grasses. Genetic Research, Cambridge 77:213-218.

Burd, A. D., F. Gould, J. R. Bradley, J. W. van Duyn, and W. J. Moar. 2003. Estimated frequency of nonrecessive $B t$ resistance genes in bollworm, Helicoverpa zea (Boddie) (Lepidoptera: Noctuidae) in eastern North Carolina. Journal of Economic Entomology 96:137-142.

Ceccarelli, S., W. Erskine, J. Hamblin, and S. Grando. 1994. Genotype by environment interaction and international breeding programmes. Experimental Agriculture 30:177-187.

Chilcutt, C. F., and B. E. Tabashnik. 2004. Contamination of refuges by Bacillus thuringiensis toxin genes from transgenic maize. Proceedings of the National Academy of Sciences of the United States of America 101:7526-7529.

Chrispeels, M. 2000. Biotechnology and the poor. Plant Physiology 124:3-6.

Cleveland, D. A. 2001. Is plant breeding science objective truth or social construction? The case of yield stability. Agriculture and Human Values 18 (3):251-270.

Cleveland, D. A., D. Soleri, F. Aragón Cuevas, M. R. Fuentes Lopez, and H. Ríos Labrada. 2004. Evaluating the potential impact of transgenic crop varieties in the Third World: documenting farmers' perspectives. Invited presentation at Bringing transgenic foods into the marketplace (plant breeding issues). 31 October-4 November 2004. Crop Science Society of America, Seattle, Washington, USA.

Cleveland, D. A., D. Soleri, and S. E. Smith. 2000. A biological framework for understanding farmers' plant breeding. Economic Botany 54:377-394.

Cohen, J. H. 2001. Transnational migration in rural Oaxaca, Mexico: dependency, development, and the household. American Anthropologist 103:954967.

Commission for Environmental Cooperation of North America (CEC). 2004. Maize and biodiversity: the effects of transgenic maize in Mexico. Key findings and recommendations. Secretariat article 13 report. CEC, Montreal, 
Quebec, Canada. (Online.) URL:

http://www.cec.org/files/PDF//Maize-and-Biodiversity en. pdf.

Conference of the Parties to the Convention on Biological Diversity (COP CBD). 2000. Cartagena Protocol on Biosafety. (Online.) URL: http://www.biodiv.org/biosafety/protocol.asp.

Consultative Group on International Agricultural Research (CGIAR). 2004. Kenya prepares to grow insect-resistant maize. CGIAR News. CGIAR, Washington, D.C., USA. (Online.) URL:

http://www.cgiar.org/enews/sept2004/story 16.html

Conway, G. 2003. From the green revolution to the biotechnology revolution: food for poor people in the $21^{\text {st }}$ century. Woodrow Wilson International Center for Scholars Director's Forum, 12 March 2003. Rockefeller Foundation, New York, New York, USA. (Online.) URL:

http://www.rockfound.org/documents/566/Conway. pdf.

Costanza, R. 2001. Visions, values, valuation, and the need for ecological economics. BioScience 51:459-468.

Cromwell, E., S. Wiggins, and S. Wentzel. 1993. Sowing beyond the State. Overseas Development Institute, London, UK.

Dalton, R. 2001. Transgenic corn found growing in Mexico. Nature 413:337.

Daniell, H. 2002. Molecular strategies for gene containment in transgenic crops. Nature Biotechnology 20:581-586.

Davis, M. A. 2003. Biotic globalization: does competition from introduced species threaten biodiversity? BioScience 53:481-489.

DeSantis, S. R. 2003. Control through contamination: U.S. forcing GMO corn and free trade on Mexico and Central America. Institute for Social Ecology Biotechnology Project, and Action for the Community and the Ecology in the Regions of Central America (ACERCA), a project of Action for Social and Ecological Justice (ASEJ), Burlington, Vermont, USA. (Online.) URL:

http://www.nerage.org/archives/CA\%20report\%20final. $\underline{\mathrm{rtf} \text { ?PHPSESSID=6f11758f4bf71f00c9729f2011c6d9c3 }}$
DeVries, J., and G. Toenniessen. 2001. Securing the harvest: biotechnology, breeding and seed systems for African crops. CAB International Publishing, Wallingford, UK.

Dietz, T., R. S. Frey, and E. A. Rosa. 2002. Risk, technology, and society. Pages 329-369 in R. E. Dunlap and W. Michelson, editors. Handbook of environmental sociology. Greenwood Press, Westport, Connecticut, USA.

Eastham, K., and J. Sweet. 2002. Genetically modified organisms (GMOs): the significance of gene flow through pollen transfer. European Environment Agency, Copenhagen, Denmark.

Economic and Social Research Council (ESRC). 1999. The politics of GM food: risk, science and public trust. ESRC Global Environmental Change Programme, University of Sussex, Falmer, Brighton, U.K.

Elias, M., L. Penet, P. Vindry, D. McKey, O. Panaud, and T. Robert. 2001. Unmanaged sexual reproduction and the dynamics of genetic diversity of a vegetatively propagated crop plant, cassava (Manihot esculenta Crantz), in a traditional farming system. Molecular Ecology 10:1895-1907.

Ellis, F. 1993. Peasant economics: farm households and agrarian development. Second edition. Cambridge University Press, Cambridge, UK.

Ellstrand, N. C. 2003a. Current knowledge of gene flow in plants: implications for transgene flow. Philosophical Transactions of the Royal Society of London B 358:1163-1170.

Ellstrand, N. C. 2003b. Dangerous liaisons? When cultivated plants mate with their wild relatives. Johns Hopkins University Press, Baltimore, Maryland, USA.

Ellstrand, N. C. 2003c. Going to "great lengths" to prevent the escape of genes that produce specialty chemicals. Plant Physiology 132:1770-1774.

Endler, J. A. 1986. Natural selection in the wild. Princeton University Press, Princeton, New Jersey, USA.

ETC Group. 2003. Maize rage in Mexico. (Online.) 


\section{URL:http://www.etcgroup.org}

European Economic and Social Committee (EECS). 2002. Economic and Social Committee adopts opinion on GM labeling. Brussels, Belgium. (Online.) URL:

http://ica.cordis.lu/search/index.cfm?fuseaction=news. simpledocument\&N RCN=18486\&CFID=791740\&CFTOKEN=95620260.

Evans, L. T. 1993. Crop evolution, adaptation and yield. Cambridge University Press, Cambridge, UK.

Evans, L. T. 1998. Feeding the ten billion: plants and population growth. Cambridge University Press, Cambridge, UK.

Falkenmark, M. 1994. Landscape as life-support provier: water-related limitations. Pages 103-116 in F. Graham-Smith, editor. Population, the complex reality. The Royal Society, London, UK.

Food and Agriculture Organization (FAO). 2004a. Agricultural biotechnology: meeting the needs of the poor? in T. Raney, editor. The state of food and agriculture. FAO, United Nations, Rome, Italy.

FAO. 2004b. FAO agricultural data. FAOSTAT data base. (Online.) URL:

http://apps.fao.org/page/collections?subset=agriculture

Farrow, S. 2004. Using risk assessment, benefitcost analysis, and real options to implement a precautionary principle. Risk Analysis 24:727-735.

Federoff, N. 2003. Prehistoric GM corn. Science 302:1158-1159.

Fermin, G., V. Inglessis, C. Garboza, S. Rangel, M. Dagert, and D. Gonsalves. 2004. Engineered resistance against Papaya ringspot virus in Venezuelan transgenic papayas. Plant Disease 88:516-522.

Fitt, G. P., D.A . Andow, Y Carriére, W. J. Moar, T. H. Schuler, C. Omoto, J. Kanya, M. A. Okech, P. Arama, and N. K. Maniania. 2004. Resistance risks and management associated with $B t$ maize in Kenya. Pages 209-250 in A. Hilbeck and D. A. Andow, editors. Environmental risk assessment of genetically modified organisms. Volume 1. A Case Study of Bt Maize in Kenya. CAB International,
Wallington, UK.

Freudenberg, W. R. 1988. Perceived risk, real risk: social science and the art of probabalistic risk assessment. Science 242:44-49.

Frewer, L. 2003. Societal issues and public attitudes towards genetically modified foods. Trends in Food Science \& Technology 14:319-332.

Frewer, L. J. 1999. Risk perception, social trust, and public participation into strategic decision making-implications for emerging technologies. Ambio 228:569-574.

Frewer, L. J., S. Miles, and R. Marsh. 2002. The media and genetically modified foods: evidence in support of social amplification of risk. RiskAnalysis 22:701-711.

Frey, K. J. 1996. National plant breeding study - 1: human and financial resources devoted to plant breeding research and development in the United States in 1994. Iowa State University, Iowa Agriculture and Home Economics Experiment Station, Ames, Iowa, USA.

Gahan, L. J., F. Gould, and D. G. Heckel. 2001. Identification of a gene associated with $B t$ resistance in Heliothis virescens. Science 293:857-860.

Génissel, A., S. Augustin, C. Courtin, G. Pilate, P. Lorme, and D. Bourguet. 2003. Initial frequency of alleles conferring resistance to Bacillus thuringiensis poplar in a field population of Chrysomela tremulae. Journal of Economic Entomology 95:14-21.

Gepts, P. 2002. A comparison between crop domestication, classical plant breeding, and genetic engineering. Crop Science 42:1780-1790.

Giddings, V. 2002. [Letter to the editor.] Nature Biotechnology 20:1081.

Goklany, I. M. 2002. From precautionary principle to risk-risk analysis. Nature Biotechnology 20:1075.

Gonsalves, D. 1998. Control of papaya ringspot virus in papaya: a case study. Annual Review of Phytopathology 36:415-437.

Gould, F., and M. B. Cohen. 2000. Sustainable use of genetically modified crops in developing 
countries. Pages 139-146 in G. Persley and M. Lantin, editors. Agricultural biotechnology and the poor: an international conference. CGIAR, Washington, D.C., USA.

Graff, G. D., S. E. Cullen, K. J. Bradford, D. Zilberman, and A. B. Bennett. 2003. The publicprivate structure of intellectual property ownership in agricultural biotechnology. Nature Biotechnology 21:989-995.

Genetic Resources Action International (GRAIN). 2004a. More information on papaya contamination in Thailand: Thai officials admit problem, contamination raises worries about patent infringement. (Online.) URL:

http://www.grain.org/research/contamination.cfm? $\underline{\mathrm{id}=167 .}$.

Genetic Resources Action International (GRAIN). $2004 b$. What's in a name? (more than you might think). Seedling July.

Greenpeace. 2003. The U.S. war on biosafety: renewed aggression by a rogue state. (Online.) URL:

http://www.eu.greenpeace.org/downloads/gmo/The $\%$ 20US\%20War\%20on\%20Biosafety.pdf.

Haimes, Y.Y. 1998. Risk modeling, assessment and management. John Wiley, New York, New York, USA.

Hall, L., K. Topinka, J. Huffman, and L. Davis. 2000. Pollen flow between herbicide-resistant Brassica napus is the cause of multiple-resistant $B$. napus volunteers. Weed Science 48:688-694.

Hancock, J. 2003. A framework for assessing the risk of transgenic crops. BioScience 53:512-519.

Hardaker, J. B., R. B. M. Huirne, and J. R. Anderson. 1997. Coping with risk in agriculture. CAB International, Wallingford, UK.

Harlan, J. R. 1992. Crops and man. Second edition. American Society of Agronomy, Inc. and Crop Science Society of America, Inc., Madison, Wisconsin, USA.

Heisey, P. W., and G. O. Edmeades. 1999. Part 1. Maize production in drought-stressed environments: technical options and research resource allocation. Pages 1-36 in CIMMYT, editor. World maize facts and trends 1997/98. CIMMYT, Mexico, D.F., Mexico.

Hickey, E., and A. Mittal. 2003. Voices from the south: the Third World debunks corporate myths on genetically engineered crops. Food First/Institute for Food and Development Policy and Pesticide Action Network North America, San Francisco, California, USA.

Hindar, K. 1999. Introductions at the level of genes and populations. Pages 149-161 in O. T. Sandlund, P. J. Schei, and Ö. Viken, editors. Invasive species and biodiversity management. Kluwer, Dordrecht, The Netherlands.

Huang, D., T. Chen, and M. J. J. Wang. 2001. A fuzzy set approach for event tree analysis. Fuzzy Sets and Systems 118:153-165.

Instituto Nacional de Estadística Geografía e Informática (INEGI). 2001. Sistema para la consulta del annuario estadistico. CD edition. INEGI, Aguascalientes, Aguascalientes, Mexico.

Jaenicke-Després, V., E. S. Buckler, B. D. Smith, M. T. P. Gilbert, A. Cooper, J. Doebley, and S. Pääbo. 2003. Early allelic seletion in maize as revealed by ancient DNA. Science 302:1206-1208.

Jaffe, G. 2003a. Plant trouble: are farmers squandering Bt corn technology? Center for Science in the Public Interest, Washington, D.C., USA. (Online.) URL:

http://cspinet.org/new/pdf/bt corn report.pdf.

Jaffe, G. 2003b. Planting Trouble UpdateSeptember 10, 2003. Center for Science in the Public Interest, Washington, D.C., USA. (Online.) URL:

http://cspinet.org/new/pdf/planting trouble update1. pdf.

James, C. 2003. Global review of commercialized transgenic crops: 2002. The International Service for the Acquisition of Agri-biotech Applications (ISAAA), Ithaca, New York, USA. (Online.) URL: http://www.isaaa.org/kc/CBTNews/press release/briefs30/ es b30.pdf.

James, C. 2004. Global status of commercialized transgenic crops: 2003. The International Service for the Acquisition of Agri-biotech Applications (ISAAA), Ithaca, New York, USA. 
Jayaraman, K. S. 2002. Poor crop management plagues $B t$ cotton experiment in India. Nature Biotechnology 20:1069.

Jordan, C. F. 2002. Genetic engineering, the farm crisis, and world hunger. BioScience 52:523-529.

Kaplinsky, N., D. Braun, D. Lisch, A. Hay, S. Hake, and M. Freeling. 2002. Maize transgenic results in Mexico are artefacts. Nature 416:601.

Kapuscinski, A. R. 2002. Controversies in designing useful ecological assessments of genetically engineered organisms. Pages 385-415 in D. K. Letourneau and B. Elpern Burrows, editors. Genetically engineered organisms: assessing environmental and human health effects. CRC Press, Boca Raton, Florida, USA.

Kareiva, P., I. M. Parker, and M. Pascual. 1996. Can we use experiments and models in predicting the invasiveness of genetically engineered organisms? Ecology 77:1670-1675.

Kok, E. J., and H. A. Kuiper. 2003. Comparative safety assessment for biotech crops. Trends in Biotechnology 21:439-444.

König, A. 2003. A framework for designing transgenic crops-science, safety and citizen's concerns. Nature Biotechnology 21:1274-1279.

König, A., A. Cockburn, R. W. R. Crevel, E. Debruyne, R. Grafstroem, U. Hammerling, I. Kimber, I. Knudsen, H. A. Kuiper, A. Peijnenburg, A. H. Penninks, M. Poulsen, M. Schauzu, and J. M. Wal. 2004. Assessment of the safety of foods derived from genetically modified (GM) crops. Food and Chemical Toxicology 42:1047-1088.

Leiss, W. 2001. Frankenfoods; or, the trouble with science. Pages 16-40 in W. Leiss, editor. In the chamber of risks: understanding risk controversies. McGill-Queens University Press, Montreal, Quebec, Canada.

Levidow, L. 2003. Precautionary risk assessment of $B t$ maize: what uncertainties? Journal of Invertebrate Pathology 83:113-117.

Levine, J., M. Vila, C. D'Antonio, J. Dukes, K. Grigulis, and S. Lavorel. 2003. Mechanisms underlying the impacts of exotic plant invasions.
Proceedings of the Royal Society of London Series B-Biological Sciences 270:775-781.

Lewis, H. W. 1990. Technological risk. Norton, New York, New York, USA.

Louette, D., A. Charrier, and J. Berthaud. 1997. In situ conservation of maize in Mexico: genetic diversity and maize seed management in a traditional community. Economic Botany 51:2038.

Louette, D., and M. Smale. 2000. Farmers' seed selection practices and maize variety characteristics in a traditional Mexican community. Euphytica 113:25-41.

Ludsin, S. A., and A. D. Wolfe. 2001. Biological invasion theory: Darwin's contributions from The Origin of Species. BioScience 51:780-789.

Mann, C. C. 2002a. Has GM corn invaded Mexico? Science 295: 1617-1619.

Mann, C. C. 2002b. New law could turn scientists into outlaws. Science 296:1591.

Martineau, B. 2001. First fruit: the creation of the Flavr Savr ${ }^{\mathrm{TM}}$ tomato and the birth of biotech food. McGraw-Hill, New York, New York, USA.

Massieu, Y., R. L. Gonzalez, M. Chauvet, Y. Castaneda, and R. E. Barajas. 2000. Transgenic potatoes for small-scale farmers: a case study in Mexico. Biotechnology and Development Monitor 41:6-10.

Matson, P. A., W. J. Parton, A. G. Power, and M. J. Swift. 1997. Agricultural intensification and ecosystem properties. Science 277:504-509.

Matsuoka, Y., Y. Vigouroux, M. M. Goodman, J. Sanchez G, E. Buckler, and J. Doebley. 2002. A single domestication for maize shown by multilocus microsatellite genotyping. Proceedings of the National Academy of Science 99:6080-6084.

McAfee, K. 2003. Neoliberalism on the molecular scale. Economic and genetic reductionism in biotechnology battles. Geoforum 34:203-219.

Medvinsky, A. B., A. Y. Morozov, V. V. Velkov, B. L. Li, M. S. Sokolov, and H. Malchow. 2004. Modeling the invasion of recessive $B t$-resistant 
insects: an impact on transgenic plants. Journal of Theoretical Biology 231:121-127.

Mellon, M., and J. Rissler. 2004. Gone to seed: transgenic contaminants in the traditional seed supply. Union of Concerned Scientists, Cambridge, Massachusetts, USA.

Metz, M., and J. Fütterer. 2002. Suspect evidence of transgenic contamination. Nature 416:600-601.

Miller, H. 2003. Will we reap what biopharming sows? Nature Biotechnology 21:480-481.

Monsanto Company. 2004. Growing options. Monsanto 2004 pledge report. Monstanto Company, St Louis, Missouri, USA. (Online.) URL: http://www.monsanto.com/monsanto/content/media/ pubs/2004/pledgereport.pdf.

Nadal, A., and T. A. Wise. 2004. The environmental costs of agricultural trade liberalization: MexicoU.S. maize trade under NAFTA. Discussion Paper Number 4. Working Group on Development and Environment in the Americas. (Online.) URL:

http://ase.tufts.edu/gdae/Pubs/rp/DP04NadalWiseJuly04. pdf.

Nature. 2002. Editorial footnote. Nature 416:600.

Nature Biotechnology. 2002. Going with the flow. Nature Biotechnology 20:527.

National Corn Growers Association (NCGA). 2004. Frequently asked questions. NCGA, Washington, D.C., USA. (Online.) URL:

http://www.ncga.com/education/main/FAQ.html\#kernels

Ndjeunga, J. 2002. Local village seed systems and pearl millet seed quality in Niger. Experimental Agriculture 38:149-162.

Nelson, K. C., G. Kibata, L. Muhammad, J. O. Okuro, F. Muyekho, M. Odinho, A. Ely, and J. M. Waquil. 2004. Problem formulation and options assessment (PFOA) for genetically modified organisms: the Kenya case study. Pages 57-82 in A. Hilbeck and D. A. Andow, editors. Environmental risk assessment of genetically modified organisms, Volume 1: A case study of Bt maize in Kenya. CAB International, Walingford, UK.
National Research Council of the National Academies (NRC). 1990. Plant biotechnology research for developing countries. National Academy Press, Washington, D.C., USA.

NRC. 1996. Understanding risk: informing decisions in a democratic society. National Academy Press, Washington, D.C., USA.

NRC. 2002. Environmental effects of transgenic plants: the scope and adequacy of regulation. National Academy Press, Washington, D.C., USA.

NRC. 2004a. Biological confinement of genetically engineered organisms. National Academy Press, Washington, D.C., USA.

NRC. 2004b. Safety of genetically engineered foods: approaches to assessing unintended health effects. National Academy Press, Washington, D. C., USA.

Organisation for Economic Co-operation and Development (OECD). 1992. Safety evaluation of foods derived by modern biotechnology: concepts and principles. OECD, Paris, France.

Perales, H., S. B. Brush, and C. O. Qualset. 1998. Agronomic and economic competitiveness of maize landraces and in situ conservation in Mexico. Pages 109-126 in M. Smale, editor. Farmers, gene banks, and crop breeding: economic analyses of diversity in wheat, maize, and rice. Kluwer Academic, Norwell, Massachusetts, USA.

Perrings, C., M. Williamson, E. B. Barbier, D. Delfino, S. Dalmazzone, J. Shogren, P. Simmons, and A. Watkinson. 2002. Biological invasion risks and the public good: and economic perspective. Conservation Ecology 6:1. (Online.) URL:

http://www.ecologyandsociety.org/vol6/iss1/art1/.

Powell, K. 2003. Concerns over refuge size for EPA-approved Bt corn. Nature Biotechnology 21:467-468.

Pressoir, G., and J. Berthaud. 2004a. Patterns of population structure in maize landraces from the Central Valleys of Oaxaca in Mexico. Heredity 92:88-94.

Pressoir, G., and J. Berthaud. 2004b. Population structure and strong divergent selection shape phenotypic diversification in maize landraces. 
Heredity 92:95-101.

Qaim, M., and D. Zilberman. 2003. Yield effects of genetically modified crops in developing countries. Science 299:900-902.

Qualset, C. O., A. B. Damania, A. C. A. Zanatta, and S. B. Brush. 1997. Locally based crop plant conservation. Pages 160--175 in N. Maxted, B. Ford-Lloyd, and J. G. Hawkes, editors. Plant genetic conservation: the in situ approach. Chapman and Hall, Hants, UK.

Quist, D., and I. H. Chapela. 2001. Transgenic DNA introgressed into traditional maize landraces in Oaxaca, Mexico. Nature 414:541-543.

Quist, D., and I. H. Chapela. 2002. Quist and Chapela reply. Nature 416:602.

Ravetz, J. 2003. A paradoxical future for safety in the global knowledge economy. Futures 35:811826.

Ravetz, J. 2004. The post-normal science of precaution. Futures 36:347-357.

Ribeiro, S. 2004. The day the sun dies: contamination and resistance in Mexico. Seedling July:4-10.

Rieger, M. A., M. Lamond, C. Preston, S. Powles, and R. T. Roush. 2002. Pollen-mediated movement of herbicide resistance between commercial canola fields. Science 296:2386-2388.

Sandlund, O. T., P. J. Schei, and S. Viken. 1999. Introduction: the many aspects of the invasive alien species problem. Pages 1-7 in O. T. Sandlund, P. J. Schei, and s. Viken, editors. Invasive species and biodiversity management. Kluwer, Dordrecht, The Netherlands.

Schenkelaars Biotechnology Consultancy (SBC). 2001. GM food crops and application of substantial equivalence in the European Union. Schenkelaars Biotechnology Consultancy, Leiden, The Netherlands.

Serratos, J. A., M. C. Willcox, and F. CastilloGonzález, editors. 1997. Gene flow among maize landraces, improved maize varieties and teosinte: implications for transgenic maize. CIMMYT, Mexico, D.F., Mexico.
Shorett, P., P. Rabinow, and P. R. Billings. 2003. The changing norms of the life sciences. Nature Biotechnology 21:123-125.

Shrader-Frechette, K. 2001. Non-indigenous species and ecological explanation. Biology and Philosophy 16:507-519.

Simberloff, D. 2004. Community ecology: is it time to move on? American Naturalist 163:787-799.

Simmonds, N. W., and J. Smartt. 1999. Principles of crop improvement. Second edition. Blackwell Science Ltd., Oxford, UK.

Smale, M. 2002. Economics perspectives on collaborative plant breeding for conservation of genetic diversity on farm. Pages 83-105 in D. A. Cleveland and D. Soleri, editors. Farmers, scientists and plant breeding: integrating knowledge and practice. CAB International, Wallingford, UK.

Smith, B. D. 1995. The emergence of agriculture. Second edition. Scientific American Library, New York, New York, USA.

Smyth, S., G. C. Khachatourians, and P. W. B. Phillips. 2002. Liabilities and economics of transgenic crops. Nature Biotechnology 20:537541.

Snow, A. A. 2002a. Possible phenotypic effects of genetically modified pathways on gene flow from field tests. Pages 63-67 in L. L. Wolfenbarger, editor. Proceedings of a workshop on: criteria for field testing of plants with engineered regulatory, metabolic, and signaling pathways. Information Systems for Biotechnology, Blacksburg, Virginia, USA.

Snow, A. A. 2002b. Transgenic crops-why gene flow matters. Nature Biotechnology 20:542.

Snow,A.A., D.A.Andow, P. Gepts, E. Hallerman, A. Power, J. Tiedje, and L. L. Wolfenbarger. 2005. Genetically engineered organisms and the environment: current status and recommendations. (ESA position paper submitted to the ESA Governing Board 21 November 2003; accepted by the ESA Governing Board 26 February 2004). Ecological Applications: in press. (Online.) URL: http://www.esa.org/pao/esaPositions/pdfDocuments/ GEO-POSITION-PAPER AUG04.pdf. 
Soleri, D., and D. A. Cleveland. 2001. Farmers' genetic perceptions regarding their crop populations: an example with maize in the Central Valleys of Oaxaca, Mexico. Economic Botany 55:106-128.

Soleri, D., and D. A. Cleveland. 2004. Farmer selection and conservation of crop varieties. Pages 433-438 in R. M. Goodman, editor. Encyclopedia of plant and crop science. Marcel Dekker, New York, New York, USA.

Soleri, D., and D. A. Cleveland. 2005. Scenarios as a tool for eliciting and understanding farmers' biological knowledge. Field Methods 17:in press.

Soleri, D., D. A. Cleveland, and F. Aragón Cuevas. 2003. Improving the relevance for and participation of farmers in risk assessment of agricultural transgenes. Invited presentation at Gene flow: what does it mean for biodiversity and centers of origin. Sponsored by the Pew Initiative on Food and Biotechnology (PIFB) and Fundación MéxicoEstados Unidos para la Ciencia (FUMEC), Mexico City. (Online.) URL:

http://pewagbiotech.org/events/0929/presentations/ soleri.pdf.

Soleri, D., D. A. Cleveland, D. Eriacho, F. Bowannie, Jr., A. Laahty, and Zuni Community Members. 1994. Gifts from the Creator: intellectual property rights and folk crop varieties. Pages $21-40$ in T. Greaves, editor. IPR for indigenous peoples: a sourcebook. Society for Applied Anthropology, Oklahoma City, Oklahoma, USA.

Soleri, D., D. A. Cleveland, S. E. Smith, S. Ceccarelli, S. Grando, R. B. Rana, D. Rijal, and H. Ríos Labrada. 2002. Understanding farmers' knowledge as the basis for collaboration with plant breeders: methodological development and examples from ongoing research in Mexico, Syria, Cuba, and Nepal. Pages 19-60 in D. A. Cleveland and D. Soleri, editors. Farmers, scientists and plant breeding: integrating knowledge and practice. $\mathrm{CAB}$ International, Wallingford, UK.

Soleri, D., S. E. Smith, and D. A. Cleveland. 2000. Evaluating the potential for farmer and plant breeder collaboration: a case study of farmer maize selection in Oaxaca, Mexico. Euphytica 116:41-57.

Suarez, A. V., M. Benard, N. D. Tsutsui, T. A. Blackledge, K. Copren, E. M. Sarnat, A. L. Wild, W. M. Getz, P. T. Starks, K. Will, P. J. Palsbøll,
M. E. Hauber, C. Moritz, and A. D. Richman. 2002. Letter to the editor. Nature 417:897.

Syngenta. 2004. Biotechnology. Syngenta, Basel, Switzerland. (Online.) URL:

http://www.syngenta.com/en/about syngenta/biotech faq. aspx\#cangm.

Taylor, M. R. 2003. Rethinking U.S. leadership in food biotechnology. Nature Biotechnology 21:852854.

Tilman, D., K. G. Cassman, P. A. Matson, R. Naylor, and S. Polasky. 2002. Agricultural sustainability and intensive production practices. Nature 418:671-677.

Tingley, D. 2004. Pages 41-67 in Proceedings, Maize and biodiversity symposium: the effects of transgenic maize in Mexico. 11 March 2004, Oaxaca, Mexico. Commission for Environmental Cooperation, Montreal, Canada. (Online.) URL: http://www.cec.org/pubs docs/documents/index.cfm? varlan=english\&ID=1456.

Todaro, M. P. 1994. Economic Development. Fifth edition. Longman, New York, New York, USA.

Union of Concerned Scientists (UCS). 2003. Pharm and industrial crops: the next wave of biotechnology. Union of Concerned Scientists, Cambridge, Massachussetts, USA. (Online.) URL: http://www.ucsusa.org/publication.cfm?publicationID $=538$

United Nations Environment Programme (UNEP). 2002. Report on the impacts of the application of genetic use restriction technologies on indigenous and local communities and farmers' rights. Conference of the Parties to the Convention on Biological Diversity, Sixth meeting, The Hague, 7-9 April 2002, Item 16 of the provisional agenda. Addendum. UNEP/CBD/COP/6/11/Add.1. (Online.) URL:

http://www.biodiv.org/doc/meetings/cop/cop-06/official/ cop-06-11-add1-en.pdf.

U.S. Agency for International Development (USAID). 2002. Environmental consideration for bio-engineered crops in U.S. food aid donations. USAID, Washington, D.C., USA. (Online.) URL: http://www.usaid.gov/press/releases/2002/fs021202 1. html. 
USAID. 2003. Biotechnology. USAID, Washington, D.C., USA. (Online.) URL:

http://www.usaid.gov/our work/agriculture/biotechnology/ index.html.

USDA Animal and Plant Health Inspection Service, Biotechnology Regulatory Services (USDA APHIS BRS). 2004. International activities of BRS. USDA, Riverdale, Maryland, USA. (Online.) URL:

http://www.aphis.usda.gov/brs/international intro.html

USDA Foreign Agricultural Service (USDA FAS). 2004. FAS A gricultural Export Commodity Aggregations. USDA FAS, Washinton, D.C., USA. (Online.) URL:http://www.fas.usda.gov/ustrade/

USDA Grain Inspection, Packers and Stockyards Administration (USDA GIPSA). 2002. "To whom it may concern," letter from David R. Shipman, Acting Administrator. USDA GIPSA, Washington, D.C., USA. (Online.) URL:

http://www.usda.gov/gipsa/biotech/statements/statementcorn.pdf.

USDA National Agricultural Statistics Service (USDA NASS). 2003. Corn and biotechnology special analysis. USDA NASS, Washington, D.C., USA. (Online.) URL:

http://www.usda.gov/nass/pubs/bioc0703.pdf.

USDA NASS. 2004. Crop Production-Prospective Planting-Supplement. USDA NASS, Washington, D.C., USA. (Online.) URL:

http://www.nass.usda.gov/census/census02/volume1/

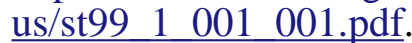

USDS Bureau of Economic and Business Affairs (USDS BEBA). 2003. Agricultural development and trade issues for bio-engineered corps in U.S. food aid donations. USDS BEBA, Washington, D. C., USA. (Online.) URL: http://www.state.gov/e/ $\mathrm{eb} / \mathrm{rls} / \mathrm{fs} / 15607 . h \mathrm{tm}$.

Vasil, I. K. 2003. The science and politics of plant biotechnology - a personal perspective. Nature Biotechnology 21:849-851.

Vélez Ascencio, O. 2003. Encuentran en la Sierra Juarez maíz transgénico prohibido en EU. Noticias (Oaxaca):9A.

Victor, D. G., and C. F. Runge. 2002. Farming the genetic frontier. Foreign Affairs 31:107-121.

Vitousek, P. M., H.A. Mooney, J. Lubchenco, and J. M. Melillo. 1997. Human domination of Earth's ecosystems. Science 277:494-499.

vom Brocke, K., E. Weltzien, A. Christinck, T. Presterl, and H. H. Geiger. 2003. Effects of farmers' seed management on performance and adaptation of pearl millet in Rajasthan, India. Euphytica 130:267-280.

Watrud, L. S., E. H. Lee, A. Fairbrother, C. Burdick, J. R. Reichman, M. Bollman, M.Storm, G. King, and P. K. van de Water. 2004. Evidence for landscape-level, pollen-mediated gene flow from genetically modified creeping bentgrass with CP4 EPSPS as a marker. Proceedings of the National Academy of Science 101:14533-14538.

Wilkinson, M. J., L. J. Elliott, J. $\quad$ l. Allainguillaume, M. W. Shaw, C. Norris, R. Welters, M. Alexander, J. Sweet, and D. C. Mason. 2003. Hybridization between Brassica napus and $B$. rapa on a national scale in the United Kingdom. Science 302:457-459.

Wong, E. Y., R. A. Ponce, S. Farrow, S. M. Bartell, R. C. Lee, and E. M. Faustman. 2003. Comparative risk and policy analysis in environmental health. Risk Analysis 23:1337-1349.

Worthy, K., R. C. Strohman, and P. R. Billings. 2002. Letter to the editor. Nature 417:897.

Zahniser, S., and W. Coyle. 2004. U.S-Mexico corn trade during the NAFTA era: new twists to an old story. Electronic Outlook Report from the Economic Research Service. Economic Research Service (ERS), U.S. Department of Agriculture, Washington, D.C., USA. (Online.) URL: http://www.ers.usda.gov/publications/FDS/may04/ fds04D01/. 